\title{
Diagnosis for ecological intensification of maize-based smallholder farming systems in the Costa Chica, Mexico
}

\author{
D. Flores-Sanchez $\cdot$ J. Kleine Koerkamp-Rabelista $\cdot$ \\ H. Navarro-Garza $\cdot$ E. A. Lantinga $\cdot$ J. C. J. Groot • \\ M. J. Kropff • W. A. H. Rossing
}

Received: 2 May 2011/Accepted: 30 August 2011/Published online: 4 October 2011

(C) The Author(s) 2011. This article is published with open access at Springerlink.com

\begin{abstract}
Enhanced utilization of ecological processes for food and feed production as part of the notion of ecological intensification starts from location-specific knowledge of production constraints. A diagnostic systems approach which combined socialeconomic and production ecological methods at farm and field level was developed and applied to diagnose
\end{abstract}

D. Flores-Sanchez · J. Kleine Koerkamp-Rabelista . E. A. Lantinga · J. C. J. Groot · W. A. H. Rossing ( $\varangle)$ Department of Plant Sciences, Biological Farming Systems group, Wageningen University, Droevendaalsesteeg 1, 6708 PB Wageningen,

The Netherlands

e-mail: walter.rossing@wur.nl

D. Flores-Sanchez

Agroecologia, Colegio de Postgraduados, Km 36.5 Carretera México-Texcoco, C.P. 56230 Montecillo, Edo. de México, Mexico

e-mail: dfs@colpos.mx

\section{H. Navarro-Garza}

Desarrollo Rural, Colegio de Postgraduados, Km 36.5 Carretera México-Texcoco, C.P. 56230 Montecillo, Edo. de México, Mexico

e-mail: hermnava@colpos.mx

\section{J. Kropff}

Department of Plant Sciences, Crop and Weed Ecology group, Wageningen University, Droevendaalsesteeg 1, 6708 PB Wageningen, The Netherlands

e-mail: martin.kropff@wur.nl extent and causes of the perceived low productivity of maize-based smallholder systems in two communities of the Costa Chica in South West Mexico. Socialeconomic and production ecological surveys were applied and complemented with model-based calculations. The results demonstrated that current nutrient management of crops has promoted nutrition imbalances, resulting in $\mathrm{K}$ - and, less surprisingly $\mathrm{N}$-limited production conditions, reflected in low yields of the major crops maize and roselle and low resource use efficiencies. Production on moderate to steep slopes was estimated to result in considerable losses of soil and organic matter. Poor crop production, lack of specific animal fodder production systems and strong dependence on animal grazing within communal areas limited recycling of nutrients through manure. In combination with low prices for the roselle cash crop, farmers are caught in a vicious cycle of cash shortage and resource decline. The production ecological findings complemented farmers opinions by providing more insight in background and extent of livelihood constraints. Changing fertilizer subsidies and rethinking animal fodder production as well as use of communal lands requires targeting both formal and informal governance structures. The methodology has broader applicability in smallholder systems in view of its low demand on capital intensive resources.

Keywords Diagnosis - Farming systems $\cdot$ Nutrient use efficiency $\cdot$ Nutrient balance $\cdot$ Plant nutrition . Erosion $\cdot$ Maize 


\section{Introduction}

The majority of farmers in Central America are smallholders who produce on small plots of land, often in marginal environments (Altieri 2002). These regions with high agroecological variability tend to be complex and diverse. Farming systems are centered around maize, which has a key role both culturally and nutritionally. Depending on the level of production, farmers produce for local markets or focus on selfsufficiency. Rural development policies have generally emphasized external inputs as a means to maintain and increase food production, as witnessed by the increase in global use of pesticides, inorganic fertilizer, animal feedstuffs, and machinery since the 1960s. The external inputs substituted natural processes and rendered resources more vulnerable to degradation (Pretty 1997; IAASTD 2009). It has become clear that in order to conserve or restore the natural resource base, rebalancing of inputs and ecosystem processes is needed. In addition to concerns about resource management, smallholders are faced with social-economic developments, such as loss of economic viability of small to medium scale farms due to increasing vertical integration of production and processing, more stringent food quality and safety requirements and increasing costs of production inputs, and the steady exodus from rural to urban areas (Safley 1998).

The Costa Chica region in Mexico is among the poorest in the country, severely lagging behind in education, housing quality and employment, as indicated by a high marginalization index value (Consejo Nacional de Poblacion 2006). In the municipality of Tecoanana farming on moderate to steep slopes constitutes the major source of livelihood with over $66 \%$ of the population involved in primary agriculture. Maize (Zea mays L.) is the major staple crop, often grown for subsistence. Roselle (Hibiscus sabdariffa L.) is grown as a cash crop, often intercropped with maize. Nitrogen $(\mathrm{N})$ and phosporus $(\mathrm{P})$ fertilizers are subsidized as part of government subsidy packages and have largely replaced fallowing as a means to restore soil fertility. Population increases cause pressure on land and contribute to intensification of crop production. Widespread use of herbicides, largely without technical advice, has replaced manual weeding and soil tillage. Despite these external inputs, maize yields are low and are perceived not to increase. Ecological intensification is an approach aimed at exploring alternative farming systems by means of integrating ecological processes in the crop and soil management (Cassman 1999; CIRAD 2010). In this approach intelligent management of ecological processes aims to complement or even replace purchased inputs (Malézieux et al. 2009). The first step towards such re-design is diagnostic and aims at identifying constraints and possible alternatives in close cooperation with farmers. The diagnosis process and its results provide a richer understanding of farmer realities by the researcher, build trust relations among researcher and farming community, and stimulate coconstruction of changes in systems management (Pretty 1995). A range of methods has been proposed to understand farmer realities, such as rapid rural appraisals, participatory rural appraisals, agroecosystem analysis (e.g. Röling et al. 2004). Tittonell et al. (2008) distinguished on-farm and computer-based methods for analysis of farming systems. The on-farm methods start from a rapid description of the farming systems in terms of agro-ecological and socio-economic components, followed by more detailed subsystems analysis. Models are used to analyze the subsystems from an agro-ecological perspective and to explore options for change.

In this paper we diagnose the extent and causes of the perceived low productivity of maize-based smallholder systems in two communities of the Costa Chica municipality of Tecoanapa. A set of on-farm methods, and social-economic and production ecological surveys were applied and complemented with modelbased calculations. The methods were used to: (a) acquire insight in the diversity of natural resource conditions and the associated management by farm households; (b) identify main production constraints and their causes at field and farm levels.

\section{Materials and methods}

General description of the study areas

The municipality of Tecoanapa $\left(16^{\circ} 48^{\prime} \mathrm{N}, 7^{\circ} 11^{\prime} \mathrm{W}\right)$ is located in Costa Chica, a hilly region on Mexico's Pacific coast in the state of Guerrero. The municipality has an area of $777 \mathrm{~km}^{2}$ and comprises 38 communities situated between 200 and 1,000 m above sea level (masl). Population was 43,128 in 2000 (INEGI 2002). Average annual rainfall in the area is 
approximately $1,300 \mathrm{~mm}$ concentrated between June and October. Maximum and minimum temperatures vary with altitude. In the highest areas (900 masl) temperature range is from 12 to $27^{\circ} \mathrm{C}$; in the middle area (300-900 masl) from 15 to $30^{\circ} \mathrm{C}$; and in the low areas (less than 300 masl) from 18 to $33^{\circ} \mathrm{C}$. (Presidencia Municipal de Tecoanapa, Gro., and Instituto de Investigación Científica Área Ciencias NaturalesUAG 2001). Most of the area is covered by forest (63\%). Agricultural land use is confined to 14,272 ha, approximately $35 \%$ of the total area. Soils in the region are of volcanic origin and predominantly classified as Regosols. Cropping is synchronized with rainfall and limited to one cropping cycle a year as most farmers do not have access to irrigation water and thus do not crop in the dry season.

\section{System diagnosis}

The diagnosis comprised of two phases, a rapid system characterization which was followed by a more detailed system characterization. Figure 1 summarizes the two phases and their respective components and methods applied. The rapid system characterization focused on obtaining information from farmers, their household situation and their management systems. Methods used over the course of 1 year included workshops during which also training on technical skills were provided, farm visits and transect walks with the farmers and surveys. The information obtained in the first phase gave elements to set up the detailed system characterization. This second phase aimed to provide insight in agronomic variables at the field level both by measurements and by calculations using models.

\section{Rapid system characterization}

After contacts with the Tecoanapa community leadership and farmers two contrasting communities were selected, Las Animas (173 households) and Xalpatlahuac ( 373 households). Las Animas was generally seen as experiencing more resource degradation than Xalpatlahuac. Also, social structures in the two villages differed, with more social control and cooperation related to natural resource use and management being in place in Xalpatlahuac, where for instance forest protection is organized, than in Las Animas. Both communities were organized in villages. The arable fields could only be reached on foot or horseback, and were dispersed in the surrounding forested area.

Several tools from Participatory Rural Appraisal and the agroecosystems approach (Chambers 1994; Ye et al. 2002) such as workshops, seasonal calendars,

Fig. 1 Methodological

framework
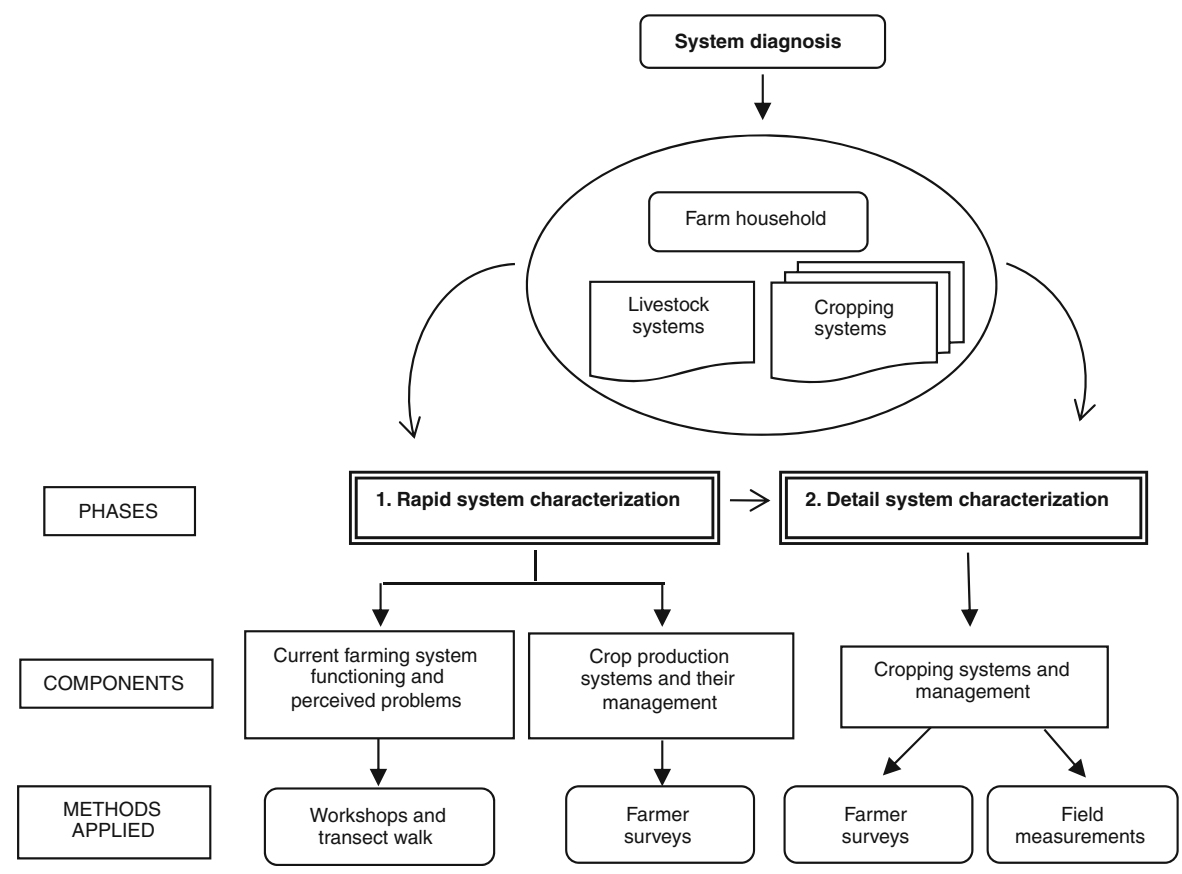
interviews, transect walks were applied to identify and understand systems, their functioning and perceived problems. Information was organized into two aspects: (1) description of farming systems and their perceived constraints; (2) description of crop production systems and their management. Farmers participating in workshops were asked to: (1) identify and rank major problems they perceived in their farming and cropping systems; (2) describe causes of the stated problems; (3) propose possible solutions to the problems and the actions needed to solve them. Accompanied by local authorities and farmers, three transect walks were carried out in each community to understand the farmer perception of variation in the landscape, the types of soils and the cropping systems in the communities.

Following the workshops, 30 farmers were invited to individually participate in a structured survey to characterize farming systems, 14 farmers in Las Animas and 16 in Xalpatlahuac. Criteria to select farmers were their well-connectedness in the community and an interest in thinking about systems redesign. The farm level survey included questions related to: (a) wealth and endowment; (b) production systems and management; (c) perceptions of land use; (d) opportunities for developing local innovations, ranked on a scale ranging from low (0) to moderate (1) and high (2). Results from surveys were organized in three domains: environmental, agronomic, and socio-economic and presented in a radar graph.

\section{Detailed system characterization}

A total of 8 farmers out of the 30 (4 from each community), previously interviewed, were invited to participate in a detailed system characterization. The farmers were selected to represent local variation in terms of availability of land, cropping and animal systems, cultural practices and socio-economic farming strategies. In a structured survey qualitative and quantitative information was sought on: (a) cropping systems: crop sequences grown and associated cultural practices, seasonal calendars/labour calendars, pest and diseases, inputs; (b) livestock: type of animals, size of herd, feeding during dry and wet seasons, animal health, inputs, manure management; (c) farm economics: commercialization and subsidies.

Each field of the 8 farmers was sampled once before maize harvest in November 2005 to characterize soil fertility and crop productivity. This resulted in 22 sampled fields. During transect walks slope, exposure or soil fertility level as described by the farmer were established. From each field top soil samples $(0-20 \mathrm{~cm})$ were taken with a shovel at 20 points per ha. The samples were mixed, and one composite sample per field was sent for analysis. The soil properties analyzed were texture (Bouyoucos hydrometer), $\mathrm{pH}$ (1:2 soil:water), soil organic matter (SOM; wet oxidation Walkley-Black), total N (Kjeldahl-N), P (Bray-1) and $\mathrm{K}$ (exchangeable by ammonium acetate at $\mathrm{pH}$ 7.0).

In each field, crop and weed aboveground biomass were sampled at 5 random locations at crop physiological maturity. Maize grain yield, roselle calyx yield and crop residues were based on samples of $5 \times 1 \mathrm{~m}^{2}$ and expressed in $\mathrm{kg} \mathrm{ha}^{-1}$ after oven drying at $70^{\circ} \mathrm{C}$ for $24 \mathrm{~h}$, adjusting maize grain moisture to $15.5 \%$ which value is used throughout this paper. Weed biomass was sampled on a subarea of $0.40 \times 0.50 \mathrm{~m}^{2}$ in the maize and roselle samples after visually estimating ground cover, and oven-dried at $70^{\circ} \mathrm{C}$ for $24 \mathrm{~h}$ to estimate aboveground biomass dry weight $\left(\mathrm{kg} \mathrm{ha}^{-1}\right)$. Plant residues, products (maize grain and roselle calyxes) and weeds were sent to the laboratory to be analyzed for N, P and $\mathrm{K}$ content. Total $\mathrm{N}$ was analyzed using the semi-micro-Kjeldahl procedure (Bremner 1965). $\mathrm{P}$ and K were analyzed by inductively coupled plasma spectrometry (ICP-AES VARIAN ${ }^{\mathrm{TM}}$ Liberty II) (Alcántar and Sandoval 1999).

To define field distance from homestead three classes were distinguished based on time spent walking: near (10-20 min), mid (between 21 and $40 \mathrm{~min}$ ) and far (more than $40 \mathrm{~min}$ ).

Data analysis

\section{Biomass—nutrient relations}

The effect of nutrient supply on maize biomass and yield was analyzed in terms of the graphical analysis proposed by Van Keulen (1982). Total nutrient uptake (N, P and K) was plotted against grain yield. The values of maximum accumulation and maximum dilution of $\mathrm{N}, \mathrm{P}$ and $\mathrm{K}$ proposed by Setiyono et al. (2010) were used as a reference for grains after adjusting to $15.5 \%$ moisture content. In case of aboveground biomass ( $\mathrm{kg} \mathrm{DM} \mathrm{ha}{ }^{-1}$ ), the accumulation and dilution lines were estimated according to the values proposed by Nijhof (1987), using the average harvest index of 0.38 established in the current study. 
Nutrient uptake was plotted as a function of $\mathrm{N}$ and $\mathrm{P}$ application (K was never applied).

Nutrient uptake was related to potential soil supply of N, P and $\mathrm{K}$ calculated according to QUEFTS (Quantitative Evaluation of the Fertility of Tropical Soils; Janssen et al. 1990). In this static model, potential indigenous soil supplies of $\mathrm{N}(\mathrm{SN}), \mathrm{P}(\mathrm{SP})$ and $\mathrm{K}(\mathrm{SK})$ on the basis of chemical soil data were estimated according to:

$$
\begin{aligned}
& \mathrm{SN}=f \mathrm{~N} * 68 * \mathrm{~N} \\
& \mathrm{SP}=f \mathrm{P} * 0.35 * \mathrm{C}+0.5 * \mathrm{P} \\
& \mathrm{SK}=(f \mathrm{~K} * 400 * \mathrm{~K}) /(2+0.9 * \mathrm{C}) \\
& f \mathrm{~N}=0.25 *(\mathrm{pH}-3) \\
& f \mathrm{P}=1-0.5 *(\mathrm{pH}-6)^{2} \\
& f \mathrm{~K}=0.625 *(3.4-0.4 * \mathrm{pH})
\end{aligned}
$$

where $\mathrm{C}$ represents soil organic carbon $\left(\mathrm{g} \mathrm{kg}^{-1}\right)$, assuming $58 \% \mathrm{C}$ in soil organic matter, $\mathrm{N}$ represents total $\mathrm{N}\left(\mathrm{g} \mathrm{kg}^{-1}\right), \mathrm{P}$ represents plant available soil phosphorus measured as P-Bray-1 ( $\mathrm{mg} \mathrm{kg}^{-1}$ ) (B. H. Janssen; personal communication), $\mathrm{K}$ represents exchangeable $\mathrm{K}\left(\mathrm{cmol} \mathrm{kg}^{-1}\right)$ and $\mathrm{pH}$ is $\mathrm{pH}\left(\mathrm{H}_{2} \mathrm{O}\right)$. Maximum recovery fractions of applied $\mathrm{N}$ and $\mathrm{P}$ were 0.5 and 0.1 , respectively as suggested by Janssen et al. (1990).

The QUEFTS model was used to predict maize grain yield both with and without fertilizer application. For this purpose, uptake rates of N, P and $\mathrm{K}$ were predicted based on the potential soil supply and fertilizer rates, and estimated nutrient recovery of applied nutrients. From nutrient uptake the yield ranges were estimated as function of the actual uptakes of $\mathrm{N}, \mathrm{P}$ and $\mathrm{K}$ considering maximum accumulation (i.e. the nutrient is not yield-limiting) and maximum dilution (i.e. the nutrient is yield-limiting). In the last step, yield was predicted based on the interactions among the three yield ranges.

\section{Soil erosion}

To estimate the annual average soil erosion the Revised Universal Soil Loss Equation (RUSLE) was used, proposed by Renard et al. (1997):

$$
\mathrm{A}=\mathrm{R} * \mathrm{~K} * \mathrm{LS} * \mathrm{C} * \mathrm{P}
$$

where $\mathrm{A}$ is the average annual soil loss per unit $\left(\mathrm{t} \mathrm{ha}{ }^{-1}\right.$ year $\left.^{-1}\right) ; \mathrm{R}$ is the rainfall erosivity factor
(MJ mm ha ${ }^{-1} \mathrm{~h}^{-1}$ year $^{-1}$ ); $\mathrm{K}$ is the soil erodibility factor ( $\mathrm{t}$ ha h $\mathrm{MJ}^{-1} \mathrm{~mm}^{-1} \mathrm{ha}^{-1}$ ) which represents the soil loss rate per erosion index unit for a specific soil. The $\mathrm{K}$ factor integrates the effect of rainfall, runoff and soil characteristics such as texture, structure, organic matter content and soil permeability on soil loss; LS is the combination of the slope length (L) and slope steepness ( $\mathrm{S}$ ) (unitless); $\mathrm{C}$ is the cover and management factor which estimates the soil loss ratio (SLR). The factor $\mathrm{C}$ integrates the effects of crop characteristics, soil cover, and soil disturbing activities on erosion and corresponds to the ratio of soil loss from an area with specified cover and management to soil loss from an identical area in tilled continuous fallow. $\mathrm{P}$ is the support practice factor: the ratio of soil loss with a support practice such as contouring or terracing, and soil loss with straight-row farming up and down the slope. The model is empirical. Here we describe adaptations to the model variables R, LS, C and $\mathrm{P}$ based on use of local data sources. The variable K was used as described by Renard et al. (1997), using expert opinion to determine the soil structure code.

Rainfall erosivity factor $(R)$ In the original model, rainfall erosivity $\mathrm{R}$ was estimated using $\mathrm{EI}_{30}$, the product of total storm energy (E) and the maximum 30 min intensity $\left(I_{30}\right)$. Since these data were not available for our study area, we estimated $\mathrm{R}$ from measured annual rainfall $(\mathrm{mm})$. The estimation is based on work by Figueroa et al. (1991) who calculated $\mathrm{R}$ for 14 different regions in Mexico using data on annual amounts of precipitation and intensity values from 53 climate stations distributed around the country. The equation for our study area was:

$\mathrm{R}=8.8938 \mathrm{x}+0.000442 \mathrm{x}^{2}$

where $\mathrm{x}$ represents measured annual rainfall $(\mathrm{mm})$.

Slope length and steepness factors (LS) The LS factor represents erodibility due to combination of slope length (L) and steepness (S) relative to a standard unit plot. Slope length (L) was calculated using the original equation (Renard et al. 1997):

$L=(\lambda / 22.1)^{\mathrm{m}}$

where $L$ is slope length factor normalized to $22.1 \mathrm{~m}$ (unit plot length); $\lambda$ is slope length; and $m$ is a parameter. According to Liu et al. (2000), $m=0.5$ is 
appropriate for steep slopes, such as in the study area where the average slope was $27 \%$. To estimate steepness (S) the equation proposed by Nearing (1997) for steep slopes was used. The equation takes the form of a logistic function. It is based on the RUSLE relationships for slopes up to $22 \%$, and was found to also fit data for slopes greater than those from which the RUSLE relationships were derived:

$\mathrm{S}=-1.5+17 /[1+\exp (2.3-6.1 \sin \theta)]$

where $\theta$ is the slope angle.

Cover management factor (C) The cover management factor reflects the effect of cropping and management practices on erosion rates. Factor $\mathrm{C}$ is calculated using the following equation (Renard et al. 1997):

$\mathrm{C}=\Sigma_{\mathrm{i}}\left(\mathrm{SLR}_{\mathrm{i}} * \mathrm{EI}_{30 \mathrm{i}}\right)$

where $\mathrm{SLR}_{\mathrm{i}}$ is the loss soil ratio during a time interval $\mathrm{i}$ of 15 days. The soil loss ratio describes the ratio of soil loss under actual conditions and losses experienced under reference conditions. $\mathrm{EI}_{30 \mathrm{i}}$ is the fraction of the yearly rainfall erosivity $(\mathrm{R})$ occurring during the same period of time that $\mathrm{SLR}_{\mathrm{i}}$ is calculated. Since only monthly rainfall data were available, $\mathrm{EI}_{30 \mathrm{i}}$ and $\mathrm{SLR}_{\mathrm{i}}$ were estimated for monthly time intervals using data from Figueroa et al. (1991) for Mexican conditions and no-tillage cropping systems with $30 \%$ residue retention.

Support practice factor $(P)$ The support practice factor $(\mathrm{P})$ is the ratio of soil loss with a specific support practice to the corresponding loss with upslope and down slope tillage. As in the study area no soil conservation practices are used to control erosion, $\mathrm{P}$ was assumed to have a value of 1 .

\section{Nutrient and OM balances at farm level}

Plant nutrient $(\mathrm{N}, \mathrm{P}, \mathrm{K})$ and organic matter (OM) balances at farm level were estimated based on quantitative estimates of the nutrient flows within the farm and across farm boundaries. The group of farms selected consisted of 1-4 fields located at 10 to more than 40 min walking distance from the homestead. For the estimation of farm level nutrient balances, the fields were pooled weighted by area. The Farm DESIGN model, a static balance model, was used to estimate flows of OM, N, P and K (Groot and Oomen 2011) between four main components; crops, animals, soil and manure. The crop component comprised the farm's land use systems, i.e. maize and roselle as monocrop, and/or maize-roselle intercrop, as well as the land use system products, i.e. maize grain, maize residues, roselle calyx, roselle residues, and weeds. The products were characterized in terms of observed yield and N, P, K contents, ash contents (Mitra and Shanker 1957; Burgess et al. 2002; Colunga et al. 2005; Harrington et al. 2006), effective organic matter (EOM) and feed value. EOM was defined as the organic matter remaining from crop residues 1 year after application. Four indicators of feed value were taken into account and derived from the literature; feed saturation value, feed structure value, energy content (in VEM; Dutch net energy for lactation) and crude protein content (Mourits et al. 2000; CVB 2008). Land use system products had one or several destinations: soil (crop residues and weeds left on the field), animals (crop residues and weeds fed to animals), home use (consumption by the farm family) and market. The animal component included cows and goats. Numbers of each animal type and average weight (450 kg per cow, $75 \mathrm{~kg}$ per goat) were specified. Feed balances and manure produced by animals were estimated for the part of the dry season that the animals were around the homestead. When local parameters were not available, standard values were taken based on expertise. Soil properties included in the model were bulk density, texture, $\mathrm{pH}\left(\mathrm{H}_{2} \mathrm{O}\right)$, soil organic matter content, and soil-N, -P and -K. Since only measurements of soil OM content were available for the $0-20 \mathrm{~cm}$ layer, we assumed that under the existing conditions of no-tillage, topsoil OM content was twice that of the subsoil (up to $40 \mathrm{~cm}$ ). This resulted in a lower overall SOM content than found in the top $20 \mathrm{~cm}$ as has been reported for no till systems (e.g. West and Post 2002). In the manure component of the model, imported fertilizers with their nutrient contents and applied amounts were specified, along with the calculated amounts of manure produced by cattle around the homestead and losses in $\mathrm{OM}$ and $\mathrm{N}$ resulting from storage in loose heaps. Details are provided in Groot and Oomen (2011). Here, we provide more details on the OM balance calculations in which adjustments to local conditions were made.

In the organic matter balance five different input and output processes were distinguished: net accumulation of root crop residues, aboveground crop residues and manure (residues and manure corrected 
for degradation during the year of production), soil OM decomposition, and erosion. The balance was calculated as the difference between input and output.

The net accumulation of root and aboveground crop residues was quantified as the amount of organic matter remaining 1 year after application (EOM) in the field (Groot and Oomen 2011). Root biomass was estimated as $15 \%$ of total crop biomass (Rodríguez 1993). The mono-component model of Yang and Janssen (2000) was used to predict EOM from the amount of roots per field and parameters calibrated on litterbag experiments in farmers' fields (FloresSanchez, unpublished data).

Of the aboveground crop residues of maize and weeds, $30 \%$ were assumed to remain in the field where they were produced, the remainder being taken up by animals. In case of farm owned animals, the resulting manure was assumed to stay within the farm. If the farm did not own animals, roaming animals were assumed to export the organic matter from the farm system. Roselle residues were assumed to be not suitable for animal consumption and remained in the field. Similarly, no export was assumed from fenced fields.

Degradation of soil organic matter in field $c, \mathrm{DOM}_{c}$ $\left(\mathrm{Mg}\right.$ year $\left.^{-1}\right)$, was calculated as

$\mathrm{DOM}_{c}=A_{c} * d * \mathrm{BD} * \mathrm{AOM}_{c} * k * 10^{-4}$

where $A_{c}$ is the area of field $c$ (ha), $d$ is soil depth (m), $\mathrm{BD}\left(\mathrm{Mg} \mathrm{m}^{-3}\right)$ is bulk density of the soil, $\mathrm{AOM}_{c}$ is the active $\mathrm{OM}$ in field $c(\%), k$ is the annual rate of SOM decomposition $\left(\%\right.$ year $\left.^{-1}\right)$ and $10^{-4}$ balances the units. $\mathrm{AOM}_{c}$ was estimated as the difference between the measured total SOM percentage and the minimum SOM percentage, estimated as function of soil texture according to the equation proposed by Rühlmann (1999) assuming 58\% C in SOM:

$C_{\min }=0.017 * B-0.001 * \exp (0.075 * B)$

where $C_{\min }$ is the minimum content of organic C (\%) and $B$ is clay and silt content (\%). Bulk density was assumed to be $1.3 \mathrm{Mg} \mathrm{m}^{-3}$, depth of the soil was taken from field measurements and degradation rate $k$ was estimated from data of Grace et al. (2002) for no-tillage conditions in long term trials at CIMMYT, central Mexico.

Erosion was considered a cause of organic matter and plant nutrient losses. Loss rates were calculated using RUSLE estimates of soil loss, multiplied by OM, $\mathrm{N}, \mathrm{P}$ or $\mathrm{K}$ fractions as established in the field survey.
Statistical analysis

A nested statistical analysis based on the residual maximum likelihood method was used to elucidate the effect of community, farmer and field on economic yield and total biomass observations. Residual maximum likelihood (REML) allows fitting models in which each observation is expressed additively in terms of fixed and random effects (Clarke 1996). The method can cope with unbalanced designs, as is the case in this study where the number of fields per farmer and the number of farmers per community differ. The REML method was applied iteratively, first including community as fixed term and farmer and fields as random terms, then including the combination community-farmer as fixed and fields as random, and finally testing all three as (nested) fixed terms. The analysis was programmed in Genstat 5 . The statistical significance of fixed terms as they were added to the model was evaluated by comparing the Wald test statistic with critical values of $F$ test $(P<0.05)$.

The soil properties were subjected to analyses of variance using SAS Version 9.1 to test the difference between communities, and to test the effect of the distance from the homestead. Means separation was performed when the $F$ test indicated significant $(P<0.05)$ differences between communities and among distance from homestead (Turkey's studentized range HSD test).

\section{Results}

Rapid system characterization

The farming systems in both communities were organized in small production units, land holdings ranging from 1.5 to 9 hectares and numbers of fields varying from 1 to 5 per farm. The cropping pattern was dominated by maize, which was generally cultivated for self consumption. Both cobs and grains were stored to satisfy the families' needs. Maize was mainly intercropped with roselle, squash (Cucurbita pepo L.) and beans (Phaseolus vulgaris L.), although maize and roselle were also grown as monocrops. The main cash crop was roselle. Squash traditionally was cultivated for self consumption, but was increasingly cultivated for seeds and had become an important source of income. Domestic prices for these crops were stagnant 
or declining as a result of decreased levels of domestic market protection in NAFTA.

The main objective of keeping animals was to build a cash resource. Donkeys, horses and mules were present on $63 \%$ of the farms (on average two per farm). They were used for transport of materials to and from the fields and in rare cases used for traction. Pigs and poultry (chickens, turkeys) were kept for domestic consumption on $50 \%$ of farms, on average five pigs per farm. Goats and cows were owned by 30 and $20 \%$ of the farms, respectively, with an average density for each type of 8 animals per farm. These animals were kept as capital and only sold in case of urgent need of cash. Calving patterns were irregular. Donkeys, goats and cows were fed through cut-and-carry foraging around the farmstead during the growing season and by roaming-grazing unfenced fields in the area which during the dry season are considered communal lands.

Farmers in both communities faced diverse environmental, technical and socio-economic constraints; however, four main problems were indicated by farmers (Table 1). Low soil fertility was the major concern of the farmers, which they attributed to abandonment of fallowing resulting in continuous maize cultivation. The main means to maintain soil fertility and crop nutrition were chemical fertilizers which were widely used, promoted by municipal government subsidies. Farmers paid 25\% of the cost of a package containing 4 bags (of $50 \mathrm{~kg}$ ) ammonium sulphate (21-00-00 N-P-K) and 3 bags di-ammonium phosphate (18-46-00 N-P-K), equivalent to $69 \mathrm{~kg} \mathrm{~N}$ and $30 \mathrm{~kg} \mathrm{P}$, meant for 2 ha. As most farmers owned more than 2 ha, farmers rationed amounts or bought extra fertilizer. Applications were made on the soil surface around the planting hole at sowing and around the plant base before tasseling. Organic matter, if applied, originated from manure of own animals and from crop residues.

Low yields, mentioned as another key problem were attributed to reliance on chemical fertilizers as the only source of plant nutrients, which according to the farmers made soils tired and 'scrawny'. Paraquat was the most common herbicide used by over $80 \%$ of the farmers. Herbicide use varied from 1 to $9 \mathrm{~L} \mathrm{ha}^{-1}$, while recommended rates were $2 \mathrm{~L} \mathrm{ha}^{-1}$. Few farmers used hand weeding to complement herbicide applications. Fertilizers and herbicides constituted the main production costs. Limited and monopolized commercialization channels put pressure on revenues and gross margins.

Other concerns indicated by farmers were the insecurity of food availability, the high dependency of inputs, soil erosion and the need to improve the quality of the roselle product to meet market standards. During workshops, high incidences of weeds, loss of biodiversity, low water retention capacity of the soil, increased incidences of pests in maize and the strong migration of youths to the USA were mentioned

Table 1 Main problems of farming systems, their causes and solutions mentioned in a survey of 30 farmers in the communities of Xalpathlahuac and Las Animas in Costa Chica, Mexico

\begin{tabular}{|c|c|c|c|}
\hline Component & Perceived problem & Suggested causes & Suggested alternatives \\
\hline Environmental & Low soil fertility $(19)^{\mathrm{a}}$ & $\begin{array}{l}\text { Chemical fertilizers are the main source of plant } \\
\text { nutrients, leading to 'superficial' soils. Manure } \\
\text { is hardly applied. Continuous cultivation has } \\
\text { replaced fallow periods. }\end{array}$ & $\begin{array}{l}\text { Use alternative sources of nutrients } \\
\text { such as manure and compost. }\end{array}$ \\
\hline Agronomic & Low yields (12) & $\begin{array}{l}\text { The soils are "tired", chemical fertilizers are the } \\
\text { main source of plant nutrients, and most of the } \\
\text { farmers use nitrogen and phosphorus fertilizers } \\
\text { only. }\end{array}$ & $\begin{array}{l}\text { Improve soil fertility by means of soil } \\
\text { management that includes both } \\
\text { chemical and organic fertilizers. } \\
\text { Promote training programs and } \\
\text { experimental trials }\end{array}$ \\
\hline \multirow[t]{2}{*}{$\begin{array}{l}\text { Socio- } \\
\text { economics }\end{array}$} & $\begin{array}{l}\text { High production costs } \\
\text { (10) }\end{array}$ & $\begin{array}{l}\text { Inputs are expensive, and they have to be } \\
\text { purchased in the market. Labor is expensive } \\
\text { due to migration. }\end{array}$ & $\begin{array}{l}\text { Training programs about efficient use } \\
\text { of input and dissemination of low } \\
\text { input technologies. }\end{array}$ \\
\hline & $\begin{array}{l}\text { Few commercialization } \\
\text { channels and low } \\
\text { prices of products }(5)\end{array}$ & $\begin{array}{l}\text { Lack of plans and infrastructure for marketing. } \\
\text { Local monopolistic intermediaries. }\end{array}$ & $\begin{array}{l}\text { Stimulate farmer organizations } \\
\text { together with the municipality to } \\
\text { search for alternative ways of } \\
\text { marketing. }\end{array}$ \\
\hline
\end{tabular}

a Number of farmers stating the issue 
as problems. In addition to causes, farmers suggested alternatives as described in Table 1, a number of which they were eager to pursue.

Figure 2 summarizes the qualitative indicators and shows that differences between the two communities are small. Compared to Las Animas, farmers in Xalpathlahuac had more fields in fallow, practiced more no-till and used less manure. Some indicators can explain the problems indicated by farmers. Low soil fertility and yields, and productions costs could be linked to the absence of crop rotation, low use of manure, unbalanced nutrient supply (mainly $\mathrm{N}$ and $\mathrm{P}$ ), and high input dependence.

Detailed system characterization

\section{Soil properties}

The texture of the majority of the fields was sandy loam (Table 2). Values for soil nutrient levels were low and $\mathrm{pH}$ indicated acidity. Soil organic matter and total soil $\mathrm{N}$ were significantly higher in Xalpathlahuac than in Las Animas $(P<0.05)$. Of the 22 fields, 7 were near, 5 were at mid distance and 10 were far from the homestead. Differences in soil chemical parameters and SOM were not significantly related to distance from the homestead.

\section{Nutrient supply and crop uptake}

Large ranges in $\mathrm{N}$ and $\mathrm{P}$ fertilization rates were observed and farmers generally over-applied $\mathrm{N}$ and under-applied $\mathrm{P}$ when compared to recommendations (Fig. 3). No statistically significant relation was found between $\mathrm{N}$ application rates and $\mathrm{N}$ uptake in the combined biomass of maize, roselle and weeds (Fig. 3a), whereas for $\mathrm{P}$ only a very small response of uptake to application $(0.17 \mathrm{~kg} / \mathrm{kg} ; P<0.05)$ was observed (Fig. 3b).

Relationships between potential nutrient supply from soil and fertilizers and nutrient uptake rates by total plant aerial biomass (of maize, roselle and weeds jointly) are presented in Fig. $4 \mathrm{a}-\mathrm{c}$, and by the maize component only in Fig. 4-f. The potential nutrient supply was calculated from soil supply (SN, SP and SK) and fertilizer application rates were corrected for the maximum recovery proposed in QUEFTS. N and K uptake was lower than the calculated potential supply, but uptake of $\mathrm{P}$ exceeded calculated potential supply. The underestimation of $\mathrm{P}$ supply may be due to underestimation of residual $\mathrm{P}$ release following years of application (van Reuler and Janssen 1996). K supply presented less variation than the $\mathrm{N}$ and $\mathrm{P}$ supply. Most of the values were concentrated
Fig. 2 Comparison of the environmental, agronomic, and socio-economic performance of farming systems in the communities of Xalpathlahuac and Las Animas in Costa Chica, Mexico as part of rapid system characterization

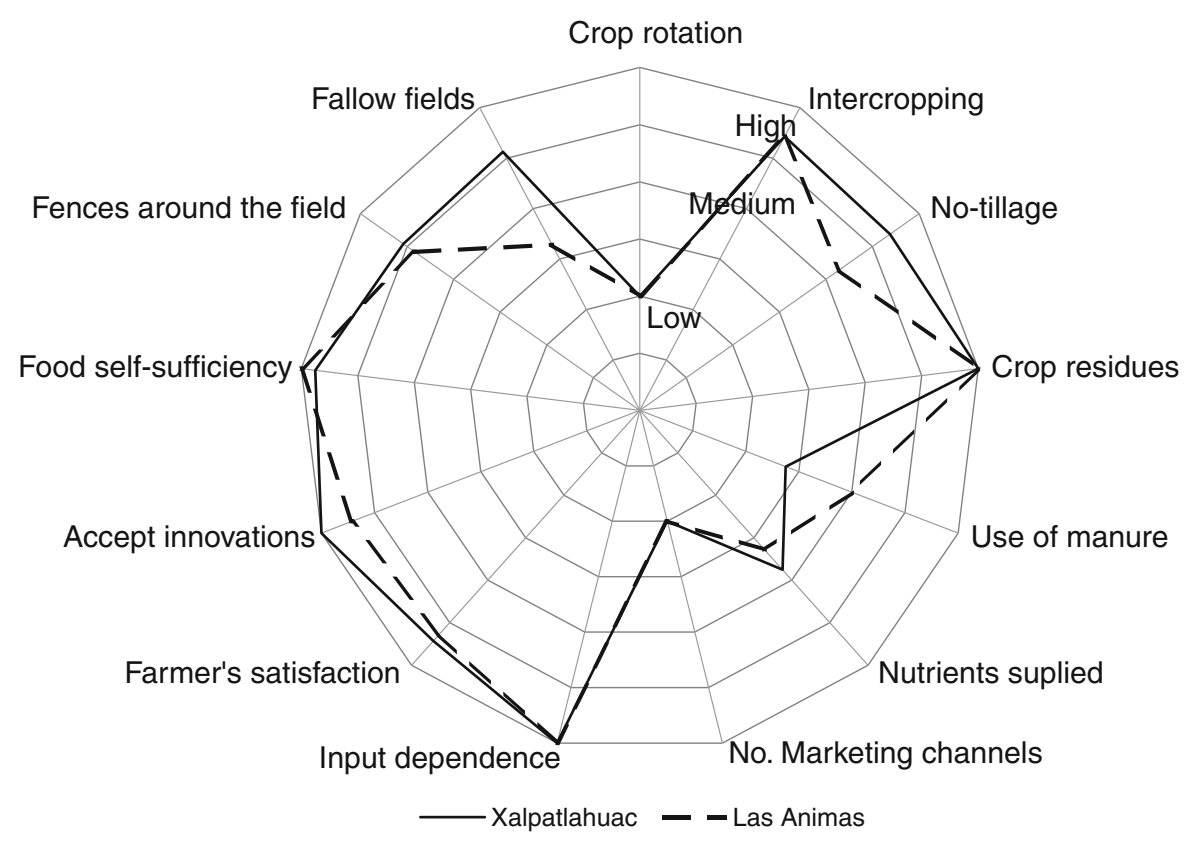


Table 2 Areas and physico-chemical properties of farmers fields in the detailed system characterization

\begin{tabular}{|c|c|c|c|c|c|c|c|c|c|c|c|c|}
\hline Farmer $^{\mathrm{a}}$ & $\begin{array}{l}\text { Area } \\
\text { (ha) }\end{array}$ & $\begin{array}{l}\text { Slope } \\
(\%)\end{array}$ & $\begin{array}{l}\text { Sand } \\
(\%)\end{array}$ & $\begin{array}{l}\text { Silt } \\
(\%)\end{array}$ & $\begin{array}{l}\text { Clay } \\
(\%)\end{array}$ & $\begin{array}{l}\text { Soil } \\
\text { texture }\end{array}$ & $\begin{array}{l}\text { Soil depth } \\
(\mathrm{cm})\end{array}$ & $\begin{array}{l}\mathrm{pH}- \\
\mathrm{H}_{2} \mathrm{O}\end{array}$ & $\begin{array}{l}\mathrm{OM} \\
\left(\mathrm{g} \mathrm{kg}^{-1}\right)\end{array}$ & $\begin{array}{l}\mathrm{Nt} \\
\left(\mathrm{g} \mathrm{kg}^{-1}\right)\end{array}$ & $\begin{array}{l}\text { Bray P-1 } \\
\left(\mathrm{mg} \mathrm{kg}^{-1}\right)\end{array}$ & $\begin{array}{l}\mathrm{K} \\
\left(\mathrm{cmol} \mathrm{kg}^{-1}\right)\end{array}$ \\
\hline A1a & 3.0 & 25 & 57 & 28 & 16 & SL & 40 & 5.3 & 11 & 0.57 & 11 & 0.24 \\
\hline $\mathrm{A} 2 \mathrm{a}$ & 1.0 & 31 & 54 & 35 & 12 & SL & 50 & 5.7 & 11 & 0.53 & 21 & 0.21 \\
\hline $\mathrm{A} 2 \mathrm{~b}$ & 1.3 & 46 & 47 & 32 & 21 & $\mathrm{~L}$ & 50 & 5.3 & 7 & 0.36 & 15 & 0.21 \\
\hline $\mathrm{A} 2 \mathrm{c}$ & 1.3 & 19 & 62 & 18 & 20 & SL & 62 & 6.0 & 27 & 1.37 & 3 & 0.28 \\
\hline $\mathrm{A} 2 \mathrm{~d}$ & 0.5 & 31 & 58 & 24 & 18 & SL & 50 & 5.4 & 16 & 0.82 & 2 & 0.17 \\
\hline $\mathrm{A} 3 \mathrm{a}$ & 1.0 & 20 & 49 & 29 & 22 & $\mathrm{~L}$ & 55 & 5.5 & 17 & 0.83 & 12 & 0.19 \\
\hline $\mathrm{A} 3 \mathrm{~b}$ & 1.0 & 20 & 49 & 37 & 14 & $\mathrm{~L}$ & 55 & 5.7 & 6 & 0.29 & 11 & 0.10 \\
\hline $\mathrm{A} 3 \mathrm{c}$ & 0.3 & 20 & 42 & 42 & 16 & $\mathrm{~L}$ & 55 & 6.1 & 10 & 0.52 & 15 & 0.16 \\
\hline $\mathrm{A} 3 \mathrm{~d}$ & 1.0 & 55 & 56 & 28 & 16 & SL & 60 & 5.5 & 9 & 0.43 & 10 & 0.09 \\
\hline $\mathrm{A} 4 \mathrm{a}$ & 0.8 & 36 & 46 & 38 & 16 & $\mathrm{~L}$ & 60 & 5.5 & 11 & 0.54 & 12 & 0.15 \\
\hline $\mathrm{A} 4 \mathrm{~b}$ & 0.8 & 36 & 50 & 34 & 16 & $\mathrm{~L}$ & 60 & 5.4 & 6 & 0.30 & 7 & 0.10 \\
\hline $\mathrm{A} 4 \mathrm{c}$ & 1.1 & 30 & 54 & 30 & 16 & SL & 40 & 5.3 & 22 & 1.11 & 27 & 0.16 \\
\hline A4d & 1.5 & 41 & 60 & 28 & 13 & SL & 60 & 5.3 & 12 & 0.59 & 14 & 0.14 \\
\hline $\mathrm{X} 1 \mathrm{a}$ & 1.5 & 21 & 38 & 34 & 28 & SL & 50 & 5.0 & 19 & 0.95 & 7 & 0.13 \\
\hline $\mathrm{X} 1 \mathrm{~b}$ & 0.5 & 21 & 45 & 34 & 21 & SL & 49 & 4.8 & 21 & 1.04 & 12 & 0.21 \\
\hline $\mathrm{X} 1 \mathrm{c}$ & 0.5 & 26 & 60 & 19 & 22 & SCL & 60 & 5.3 & 25 & 1.26 & 11 & 0.26 \\
\hline $\mathrm{X} 2 \mathrm{a}$ & 1.0 & 25 & 51 & 25 & 24 & SCL & 50 & 5.1 & 20 & 1.01 & 4 & 0.19 \\
\hline $\mathrm{X} 3 \mathrm{a}$ & 1.0 & 19 & 60 & 28 & 12 & SL & 57 & 5.1 & 10 & 0.52 & 22 & 0.14 \\
\hline $\mathrm{X} 3 \mathrm{~b}$ & 0.8 & 19 & 66 & 24 & 10 & SL & 57 & 5.0 & 20 & 0.98 & 39 & 0.13 \\
\hline $\mathrm{X} 3 \mathrm{c}$ & 1.3 & 6 & 68 & 20 & 12 & SL & 50 & 4.9 & 10 & 0.50 & 29 & 0.13 \\
\hline $\mathrm{X} 4 \mathrm{a}$ & 0.3 & 5 & 59 & 27 & 14 & SL & 65 & 5.2 & 20 & 1.02 & 5 & 0.13 \\
\hline $\mathrm{X} 4 \mathrm{~b}$ & 1.0 & 43 & 60 & 26 & 14 & SL & 54 & 5.7 & 22 & 1.08 & 6 & 0.17 \\
\hline
\end{tabular}

SL sandy loam, $L$ loam, SCL sandy clay loam

a The first letter corresponds to the community A: Las Animas, X: Xalpatlahuac, the number corresponds to the farmers and the second letter to the fields

Fig. 3 Relationship between stated application rates and measured total uptake of $\mathrm{N}(\mathbf{a})$ and $\mathrm{P}(\mathbf{b})$ by maize, roselle and weeds in different farmers' fields. Dotted lines indicate application rates recommended by the government. The solid line in $\mathrm{B}$ represents the relation between $\mathrm{P}$ application and uptake $(\mathrm{Y}=11.0+0.17 \mathrm{X}$; $\left.\mathrm{r}_{\mathrm{adj}}^{2}=0.24 ; P=0.0213\right)$; for $\mathrm{N}$ no significant relation was found
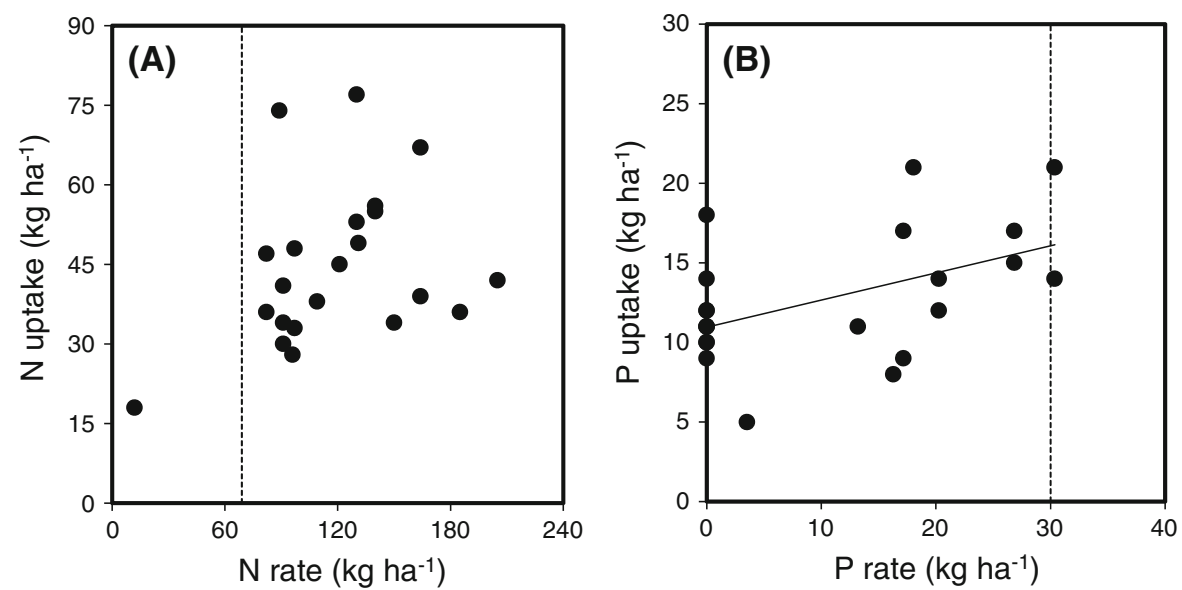

between 40 and $60 \mathrm{~kg} \mathrm{~K} \mathrm{ha}^{-1}$. External sources of $\mathrm{K}$ as chemical fertilizer are not applied by the farmers, because it was not considered in the municipal subsidies.
Nutrient uptake and crop yield

Nutrient uptake and yields of maize and roselle are presented in Table 3. Average aboveground biomass 
Fig. 4 Measured total uptake of $\mathrm{N}(\mathbf{a}, \mathbf{d}), \mathrm{P}(\mathbf{b}, \mathbf{e})$, and $\mathrm{K}(\mathbf{c}, \mathbf{f})$ by maize, roselle and weeds jointly $(\mathbf{a}-\mathbf{c})$ and by maize only (d-f) as a function of potential nutrient supply from soil calculated according to QUEFTS in Xalpatlahuac (filled circle), and Las Animas (open circle)
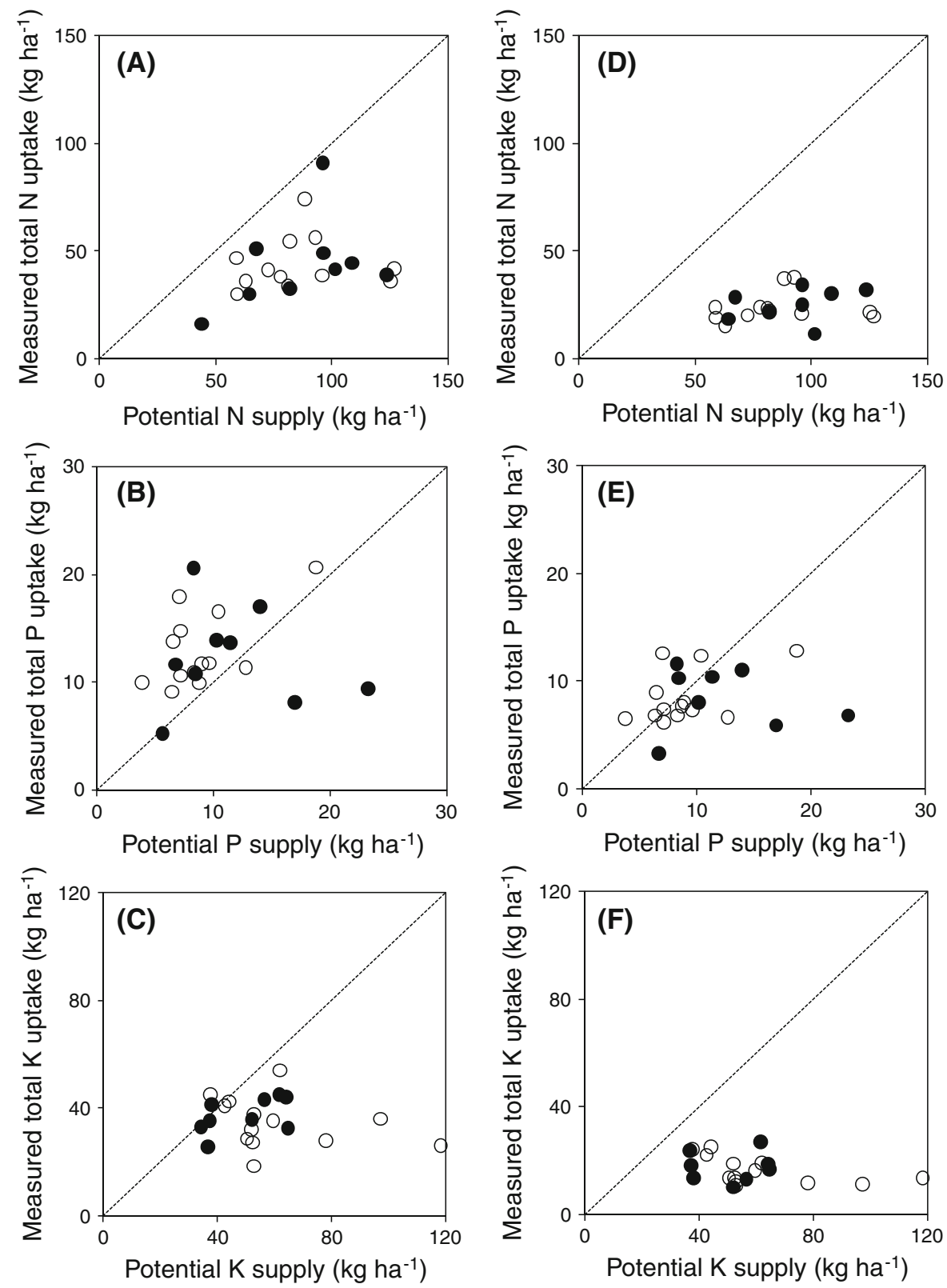

of maize in the fields ranged from 1,837 to $7,660 \mathrm{~kg} \mathrm{ha}^{-1}$, and grain yield from 763 to $3,057 \mathrm{~kg} \mathrm{ha}^{-1}$. Harvest index averaged over all fields was 0.38 . Maize biomass and grain yield were not significantly different between communities or farmers within communities, but significant differences were found among fields of farmers $(P<0.05)$.

The total uptake of nutrients by maize ranged from 11 to $44 \mathrm{~kg} \mathrm{~N}^{-1}, 2$ to $11 \mathrm{~kg} \mathrm{P} \mathrm{ha}^{-1}$ and 11 to $27 \mathrm{~kg} \mathrm{~K} \mathrm{ha}^{-1}$ (Table 3). Similar to biomass and yield, nutrient uptake was significantly different among fields of farmers, but not between farmers or communities $(P<0.05)$.

Relationships between aboveground biomass, grain yield and N, P and K uptake are presented in Fig. 5. Upper and lower boundary lines indicate the theoretical maximum dilution and accumulation of each nutrient derived from QUEFTS. Observed values for $\mathrm{N}$ in maize grains and aboveground biomass were scattered around the maximum dilution line. The same applied to K, although with a larger scatter. This indicated relative shortages for $\mathrm{N}$ and $\mathrm{K}$. In case of $\mathrm{P}$, 
Table 3 Nutrients added by farmers, average aboveground biomass, grain and calyx yield and nutrient uptake for various fields under different cropping systems in two communities

\begin{tabular}{|c|c|c|c|c|c|c|c|c|c|c|c|c|c|c|c|c|c|}
\hline \multirow[t]{2}{*}{ Farmer } & \multirow[t]{2}{*}{ Cropping system } & \multicolumn{2}{|c|}{$\begin{array}{l}\text { Nutrients } \\
\text { added } \\
\left(\mathrm{kg} \mathrm{ha}^{-1}\right)\end{array}$} & \multicolumn{5}{|c|}{ Maize $\left(\mathrm{kg} \mathrm{ha}^{-1}\right)$} & \multicolumn{5}{|c|}{ Roselle $\left(\mathrm{kg} \mathrm{DM} \mathrm{ha}{ }^{-1}\right)$} & \multicolumn{4}{|c|}{$\begin{array}{l}\text { Weeds } \\
\left(\mathrm{kg} \mathrm{DM} \mathrm{ha}^{-1}\right)\end{array}$} \\
\hline & & $\mathrm{N}$ & $\mathrm{P}$ & $\mathrm{AGB}^{\mathrm{a}}$ & Grain $^{\mathrm{b}}$ & $\mathrm{N}^{\mathrm{c}}$ & $\mathrm{P}$ & $\mathrm{K}$ & AGB & Calyx & $\mathrm{N}$ & $\mathrm{P}$ & $\mathrm{K}$ & AGB & $\mathrm{N}$ & $\mathrm{P}$ & K \\
\hline A1a & MR & 82 & 0 & 3,872 & 1,465 & 15 & 6 & 11 & 10 & 2 & 0.06 & 0.02 & 0.05 & 1,376 & 21 & 4 & 25 \\
\hline $\mathrm{A} 2 \mathrm{a}$ & MR & 205 & 0 & 3,916 & 1,483 & 20 & 7 & 12 & 196 & 22 & 0.6 & 0.2 & 0.3 & 1,077 & 22 & 5 & 16 \\
\hline $\mathrm{A} 2 \mathrm{~b}$ & MR & 164 & 0 & 3,879 & 1,584 & 21 & 7 & 13 & 1,033 & 43 & 3 & 1 & 4 & 1,139 & 15 & 3 & 9 \\
\hline $\mathrm{A} 2 \mathrm{c}$ & MR & 164 & 0 & 6,844 & 2,808 & 44 & 13 & 25 & 759 & 85 & 4 & 1 & 5 & 1,100 & 19 & 4 & 12 \\
\hline A2d & MR & 185 & 0 & 3,458 & 1,544 & 22 & 6 & 14 & 1,024 & 145 & 4 & 1 & 5 & 772 & 10 & 2 & 10 \\
\hline A3a & M & 91 & 0 & 4,251 & 1,872 & 23 & 8 & 19 & - & - & - & - & - & 665 & 11 & 2 & 13 \\
\hline $\mathrm{A} 3 \mathrm{~b}$ & M & 91 & 0 & 3,839 & 1,698 & 19 & 7 & 13 & - & - & - & - & - & 690 & 11 & 2 & 14 \\
\hline $\mathrm{A} 3 \mathrm{c}$ & M & 91 & 0 & 3,803 & 1,967 & 20 & 7 & 11 & - & - & - & - & - & 1,332 & 21 & 4 & 27 \\
\hline $\mathrm{A} 3 \mathrm{~d}$ & M & 82 & 0 & 5,098 & 2,261 & 24 & 9 & 22 & - & - & - & - & - & 2,004 & 23 & 5 & 19 \\
\hline $\mathrm{A} 4 \mathrm{a}$ & MR & 140 & 27 & 7,208 & 2,810 & 38 & 12 & 16 & 768 & 15 & 2 & 0.6 & 2 & 865 & 17 & 4 & 16 \\
\hline $\mathrm{A} 4 \mathrm{~b}$ & MR & 140 & 27 & 4,189 & 1,758 & 22 & 7 & 19 & 1,054 & 247 & 5 & 2 & 8 & 1,426 & 28 & 6 & 27 \\
\hline $\mathrm{A} 4 \mathrm{c}$ & M & 89 & 18 & 7,660 & 2,898 & 37 & 13 & 24 & - & - & & & & 1,618 & 37 & 8 & 21 \\
\hline A4d & MR & 109 & 0 & 4,464 & 1,973 & 24 & 8 & 12 & 1,291 & 121 & 6 & 2 & 2 & 571 & 8 & 2 & 4 \\
\hline X1a & M & 130 & 30 & 6,016 & 3,004 & 34 & 12 & 13 & - & - & & & & 1,954 & 43 & 9 & 28 \\
\hline $\mathrm{X} 1 \mathrm{~b}$ & M & 130 & 30 & 4,467 & 1,932 & 25 & 8 & 27 & - & - & & & & 1,271 & 28 & 6 & 18 \\
\hline $\mathrm{X} 1 \mathrm{c}$ & MR & 121 & 20 & 4,796 & 3,057 & 30 & 10 & 13 & 261 & 67 & 1 & 0.5 & 2 & 2,398 & 13 & 3 & 28 \\
\hline $\mathrm{X} 2 \mathrm{a}$ & MR & 131 & 20 & 1,837 & 763 & 11 & 3 & 10 & 941 & 103 & 3 & 1 & 6 & 1,742 & 34 & 7 & 20 \\
\hline X3a & MR & 97 & 17 & 6,441 & 2,742 & 29 & 11 & 19 & 3,227 & 122 & 16 & 5 & 20 & 462 & 4 & 1 & 5 \\
\hline $\mathrm{X} 3 \mathrm{~b}$ & MR & 97 & 17 & 3,578 & 1,687 & 22 & 7 & 18 & 741 & 110 & 3 & 0.8 & 4 & 1,092 & 8 & 2 & 13 \\
\hline $\mathrm{X} 3 \mathrm{c}$ & MR & 96 & 16 & 3,248 & 1,400 & 18 & 6 & 17 & 446 & 119 & 2 & 0.6 & 3 & 713 & 8 & 2 & 13 \\
\hline $\mathrm{X} 4 \mathrm{a}$ & $\mathrm{R}$ & 12 & 4 & - & - & & & & 5,556 & 467 & 13 & 4 & 30 & 256 & 5 & 1 & 3 \\
\hline $\mathrm{X} 4 \mathrm{~b}$ & M & 150 & 13 & 5,704 & 2,451 & 32 & 10 & 24 & - & - & - & - & - & 135 & 3 & 1 & 2 \\
\hline
\end{tabular}

$M R$ intercrop maize-roselle, $M$ maize monocrop, $R$ roselle monocrop

a Aboveground biomass on DM basis (in case of maize and roselle, including grain and calyx, respectively)

b Grain yield adjusted to $15.5 \%$ moisture

c Nutrient uptake in aboveground biomass

values for grain were close to the maximum accumulation line, while values for aboveground biomass were clustered around a line halfway the envelope suggesting optimal P-levels (Janssen and de Willigen 2006). Yields and above-ground biomass of maize did not show any signs of flattening off with increasing nutrient uptake, and regression analysis showed that a quadratic component was never significant for the relation between uptake and biomass production. This suggests that resource use was still in the lower, linear part of the response curve, thus well below attainable yield (de Wit 1992).

Roselle biomass varied between 0.01 and $5.55 \mathrm{Mg} \mathrm{ha}^{-1}$, with calyx yields varying between 2 and $467 \mathrm{~kg} \mathrm{ha}^{-1}$. Harvest index averaged over all fields was 0.13 . Nutrient uptake was very variable (Table 3) due to variation in plant density (3,200-86,000 per ha) which was the result of irregular sowing, incidence of pests and mono- versus mixed cropping systems.

Crop residues left on the field immediately after harvest amounted to an average $2.9 \mathrm{Mg} \mathrm{ha}^{-1}$ for maize, $1.1 \mathrm{Mg} \mathrm{ha}^{-1}$ for roselle and $1.1 \mathrm{Mg} \mathrm{ha}^{-1}$ for weeds. On average $34 \%$ of $\mathrm{N}, 40 \%$ of $\mathrm{P}$ and $16 \% \mathrm{~K}$ taken up in plant biomass were exported from the field in grain and calyxes. $\mathrm{N}$ uptake by weeds was on average $38 \%$ of total uptake, and about $56 \%$ of $\mathrm{N}$ remaining in the fields was captured in weeds. Thus, 
Fig. 5 Relationships between measured grain yield (a-c; $15.5 \%$ moisture) and aboveground biomass (d-f) in maize related to measured $\mathrm{N}(\mathbf{a}, \mathbf{d})$, $\mathrm{P}(\mathbf{b}, \mathbf{e})$ and $\mathrm{K}(\mathbf{c}, \mathbf{f})$ uptake in farmers' fields in Xalpatlahuac (filled circle), and Las Animas (open circle). Solid lines represent maximum nutrient dilution and dashed lines indicate maximum nutrient accumulation, as described by Nijhof (1987) and Setiyono et al. (2010)
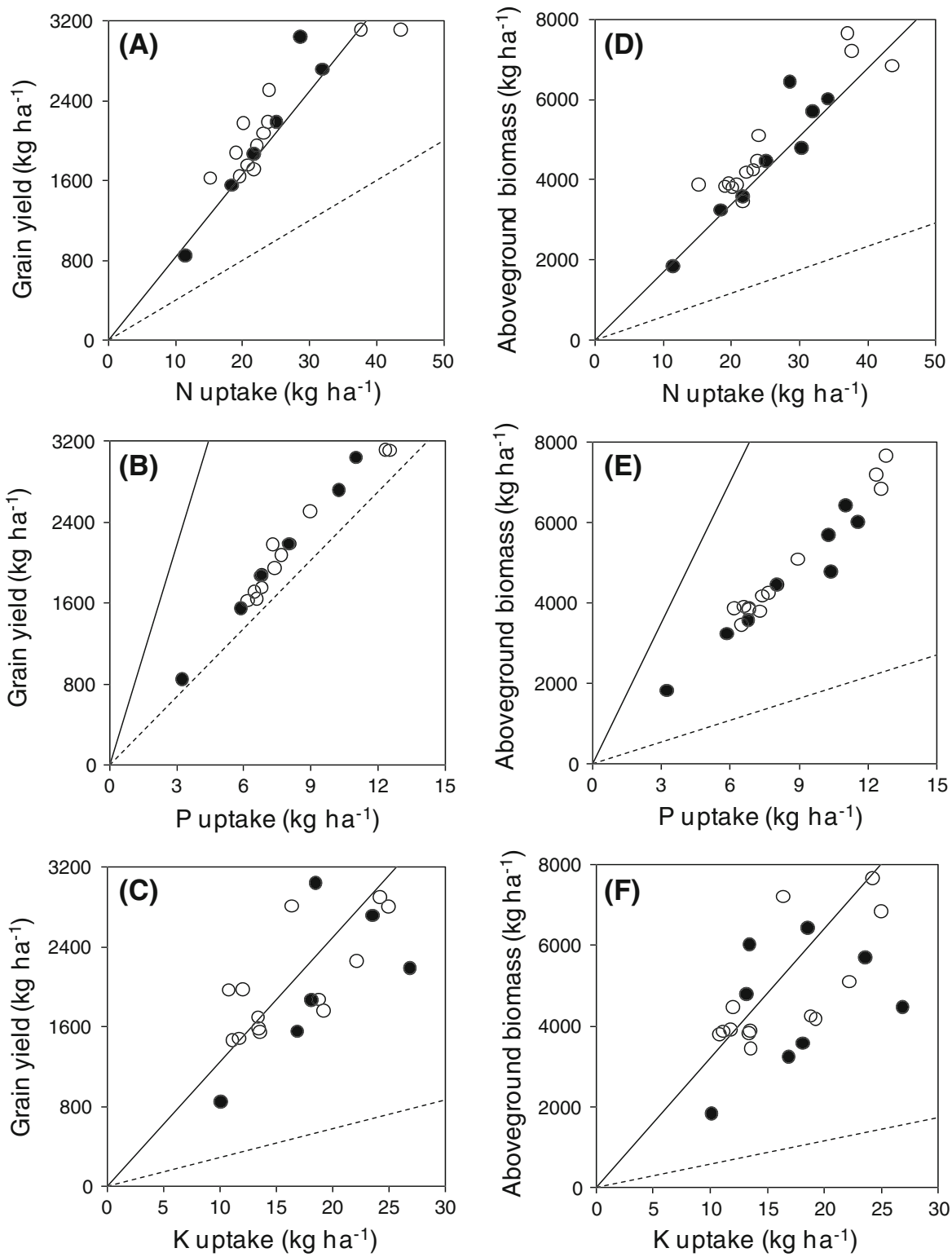

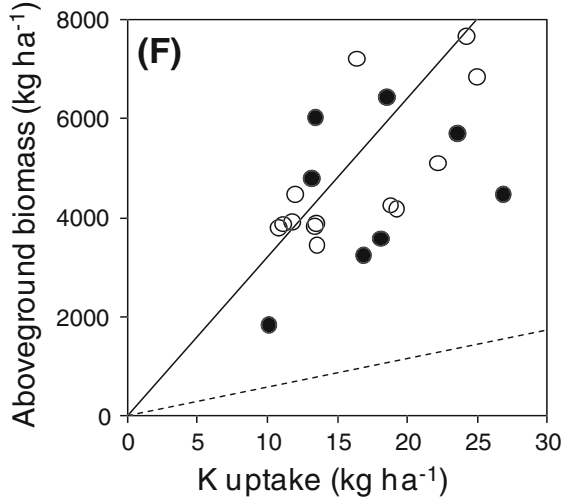

weeds contributed considerably to low crop $\mathrm{N}$ use efficiencies.

\section{Predicted yield based on potential soil nutrient supply}

Figure 6 shows the relation between measured maize grain yield and maximum attainable grain yield calculated by QUEFTS for unfertilized crops as well as based on the recorded rates of application of NPK fertilizers and the maximum recovery of nutrients for all fields in the two communities. Measured maize grain yield in both communities was on average $1973 \mathrm{~kg} \mathrm{ha}^{-1}$. Based on the default maximum recovery fractions of 0.5 for $\mathrm{N}$ and 0.1 for $\mathrm{P}$, maximum attainable yield according to QUEFTS was $3398 \mathrm{~kg} \mathrm{ha}^{-1}$ (open symbols in Fig. 6). RMSE in this case was $1578 \mathrm{~kg} \mathrm{ha}^{-1}$. An average yield of about $1503 \mathrm{~kg} \mathrm{ha}^{-1}$ would have been attainable under unfertilized conditions (closed symbols in Fig. 6), with an RMSE of $865 \mathrm{~kg} \mathrm{ha}^{-1}$. Thus, average grain yield was only $60 \%$ of the maximum attainable yields and nutrient recoveries were 


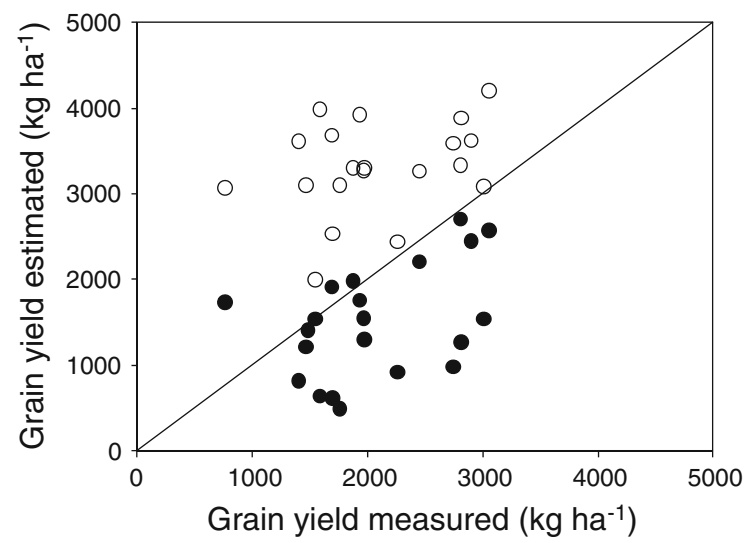

Fig. 6 Relationship between grain yield measured and grain yield estimated using QUEFTS, assuming no fertilizer input (filled circle), and maximum attainable yield based on maximum recovery of nutrients in fertilizers at application rates stated by farmers (open circle). Grain yield was adjusted to $15.5 \%$ moisture

variable and considerably lower than the proposed maximum values.

\section{Soil erosion}

Average amount of crop residue at the start of the rainy season was $2.7 \mathrm{Mg} \mathrm{ha}^{-1}$. Figueroa et al. (1991) provide data for $3 \mathrm{Mg} \mathrm{ha}^{-1}$. Using their data and assuming $30 \%$ soil cover resulted in soil erosion estimates varying from 2 to $73 \mathrm{Mg} \mathrm{ha}^{-1}$ year $^{-1}$ (Table 4). Average estimated erosion was significantly higher in Las Animas (A) than in Xalpatlahuac (X) $(t$ test, $P<0.05)$. Classification of the predicted erosion according to the classes proposed by SEMARNAT and UACH (2002) showed moderate erosion $\left(10-50 \mathrm{Mg} \mathrm{ha}^{-1}\right.$ year $\left.^{-1}\right)$ in $73 \%$ of the fields, severe erosion ( $>50 \mathrm{Mg} \mathrm{ha}^{-1}$ year $^{-1}$ ) in $14 \%$, and very slight soil erosion $\left(0-5 \mathrm{Mg} \mathrm{ha}^{-1}\right.$ year $\left.^{-1}\right)$ in another $14 \%$. Erosion rates were not correlated with the yield gap calculated in Fig. 6 (data not shown).

\section{Nutrient and OM balances at farm level}

The 8 farms analyzed with Farm DESIGN (Table 5) varied in area from 1.0 to 4.2 ha, with one to four fields per farm. The main cropping system was maize with roselle as intercrop. On four farms maize was grown as monocrop, roselle only occurred once as monocrop. Total aboveground biomass production ranged between 4,520 and $7,644 \mathrm{~kg} \mathrm{ha}^{-1}$. The sample
Table 4 Soil erosion $\mathrm{kg} \mathrm{ha}^{-1}$ year $^{-1}$ calculated with the RUSLE model assuming $3 \mathrm{Mg} \mathrm{ha}^{-1}$ of maize residues and $30 \%$ soil cover at the start of the rainy season and severity of erosion according to SEMARNAT and UACH (2002)

\begin{tabular}{|c|c|c|c|c|}
\hline \multirow[t]{2}{*}{ Farmer } & \multirow{2}{*}{$\begin{array}{l}\text { Cropping } \\
\text { system }\end{array}$} & \multirow{2}{*}{$\begin{array}{l}\text { Slope } \\
(\%)\end{array}$} & \multicolumn{2}{|c|}{ Potential soil erosion } \\
\hline & & & $\mathrm{t} \mathrm{ha}^{-1}$ year $^{-1}$ & severity \\
\hline A1a & MR & 25 & 30 & $\mathrm{~m}$ \\
\hline $\mathrm{A} 2 \mathrm{a}$ & MR & 31 & 42 & $\mathrm{~m}$ \\
\hline $\mathrm{A} 2 \mathrm{~b}$ & MR & 46 & 55 & se \\
\hline $\mathrm{A} 2 \mathrm{c}$ & MR & 19 & 5 & $\mathrm{n}$ \\
\hline $\mathrm{A} 2 \mathrm{~d}$ & MR & 31 & 26 & $\mathrm{~m}$ \\
\hline A3a & M & 20 & 20 & $\mathrm{~m}$ \\
\hline $\mathrm{A} 3 \mathrm{~b}$ & $\mathrm{M}$ & 20 & 32 & $\mathrm{~m}$ \\
\hline $\mathrm{A} 3 \mathrm{c}$ & $\mathrm{M}$ & 20 & 22 & $\mathrm{~m}$ \\
\hline A3d & M & 55 & 42 & $\mathrm{~m}$ \\
\hline $\mathrm{A} 4 \mathrm{a}$ & MR & 36 & 73 & se \\
\hline $\mathrm{A} 4 \mathrm{~b}$ & MR & 36 & 67 & se \\
\hline $\mathrm{A} 4 \mathrm{c}$ & M & 30 & 28 & $\mathrm{~m}$ \\
\hline $\mathrm{A} 4 \mathrm{~d}$ & MR & 41 & 38 & $\mathrm{~m}$ \\
\hline $\mathrm{X} 1 \mathrm{a}$ & M & 21 & 16 & $\mathrm{~m}$ \\
\hline $\mathrm{X} 1 \mathrm{~b}$ & M & 21 & 12 & $\mathrm{~m}$ \\
\hline $\mathrm{X} 1 \mathrm{c}$ & MR & 26 & 14 & $\mathrm{~m}$ \\
\hline $\mathrm{X} 2 \mathrm{a}$ & MR & 25 & 14 & $\mathrm{~m}$ \\
\hline X3a & $\mathrm{MR}$ & 19 & 23 & $\mathrm{~m}$ \\
\hline X $3 b$ & MR & 19 & 17 & $\mathrm{~m}$ \\
\hline $\mathrm{X} 3 \mathrm{c}$ & MR & 6 & 2 & vs \\
\hline $\mathrm{X} 4 \mathrm{a}$ & $\mathrm{R}$ & 5 & 2 & vs \\
\hline $\mathrm{X} 4 \mathrm{~b}$ & $\mathrm{M}$ & 43 & 30 & $\mathrm{~m}$ \\
\hline
\end{tabular}

Severity classes: vs very slight $(0-5)$; s: slight (5-10); m: moderate (10-50); se: severe (> 50)

$M R$ intercrop maize-roselle, $M$ maize monocrop, $R$ roselle monocrop

included four farms with animals; cows and goats in different combinations. Average soil erosion at farm level varied between 13 and $48 \mathrm{Mg} \mathrm{ha}^{-1}$ year $^{-1}$.

Nutrient inputs were fully based on chemical fertilizers and varied from 73 to $131 \mathrm{~kg} \mathrm{ha}^{-1}$ for $\mathrm{N}$ and from 0 to $28 \mathrm{~kg} \mathrm{ha}^{-1}$ for $\mathrm{P}$ on average (Table 5). Outputs with maize grains and roselle calyces ranged from 15 to $64 \mathrm{~kg} \mathrm{ha}^{-1}$ for $\mathrm{N}, 4$ to $14 \mathrm{~kg} \mathrm{ha}^{-1}$ for $\mathrm{P}$, and 4 to $30 \mathrm{~kg} \mathrm{ha}^{-1}$ for $\mathrm{K}$. Estimated nutrient losses by erosion varied greatly due to the varying slopes of the fields, but were for $\mathrm{N}$ on some farms as high as the amount of $\mathrm{N}$ exported in products. The balances showed an average surplus of $58 \mathrm{~kg} \mathrm{ha}^{-1}$ for $\mathrm{N}$, $5 \mathrm{~kg} \mathrm{ha}^{-1}$ for $\mathrm{P}$ and $-19 \mathrm{~kg} \mathrm{ha}^{-1}$ for K. Efficiencies 


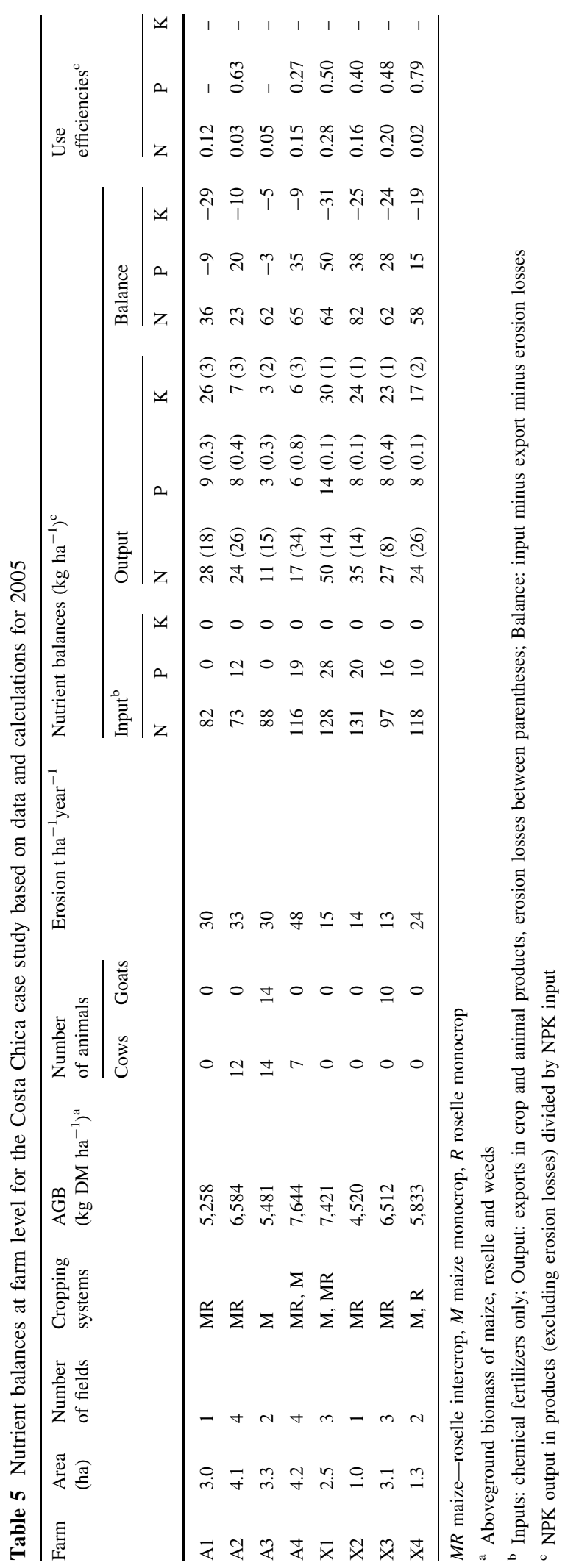

of $\mathrm{N}$ and $\mathrm{P}$ use (Table 5) were 0.12 and 0.51 on average. Animals on the farm did not lead to higher than average nutrient use efficiencies except in one case (farm A2).

OM inputs (173-1,024 $\left.\mathrm{kg} \mathrm{ha}^{-1}\right)$ and outputs (329-1,054 kg ha ${ }^{-1}$ ) varied widely among farms (Table 6). High inputs were associated with manure production and high plant biomass production. High outputs were associated with erosion. Manure was an important source of OM on farms owning animals, representing $58 \%$ of $\mathrm{OM}$ inputs on average. The $\mathrm{OM}$ losses due to soil erosion were on average $66 \%$ of total losses. Balances varied around $0 \mathrm{~kg} \mathrm{ha}^{-1}$ as can be expected for these systems where practices were maintained over at least two decades.

\section{Discussion}

Field and farm diagnosis

Smallholder farming systems in a poor region of Mexico were diagnosed using a combination of qualitative and quantitative methods that did not require important financial resources. Rapid system characterization showed that farmers face social, economic and agronomic constraints which influenced the current farming activities in the two communities in a similar way. Farming systems are strongly influenced by the external rural environment, including policies and institutions, markets and information linkages (Dixon et al. 2001). Main problems perceived by farmers were low soil fertility, low yields, high production cost and limited commercialization channels, and low prices of products.

The detailed systems diagnosis on 8 farms concentrated on the agronomic aspects and produced quantitative results. These corroborated the concerns of the farmers about low soil fertility and low yield levels, and demonstrated that $\mathrm{N}$ and $\mathrm{P}$ uptake in maize were not correlated with chemical fertilizer application rates and soil supply (Fig. 4) or with yield (not shown). Analyses with the QUEFTS model indicated that grain yield estimates were considerably lower than the attainable yield at the applied fertilizer rates, due the low nutrient recovery (Fig. 6), suggesting major resource use inefficiencies. The model assumes that fertilizer recovery is 0.50 and 0.10 for $\mathrm{N}$ and $\mathrm{P}$, respectively. Under practical conditions, these values 
Table 6 Organic matter balances for eight farms in Costa Chica, Mexico based on data and calculations for 2005

\begin{tabular}{|c|c|c|c|c|c|c|c|c|}
\hline & \multicolumn{8}{|l|}{ Farm } \\
\hline & A1 & $\mathrm{A} 2$ & A3 & A4 & $\mathrm{X} 1$ & $\mathrm{X} 2$ & $\mathrm{X} 3$ & $\mathrm{X} 4$ \\
\hline \multicolumn{9}{|l|}{ Inputs $\left(\mathrm{kg} \mathrm{ha}^{-1}\right)$} \\
\hline Root residues & 51 & 64 & 64 & 102 & 72 & 44 & 93 & 57 \\
\hline Aboveground residues & 122 & 290 & 141 & 556 & 218 & 180 & 249 & 219 \\
\hline Manure & 0 & 552 & 743 & 366 & 0 & 0 & 0 & 0 \\
\hline Total & 173 & 906 & 948 & 1,024 & 290 & 224 & 342 & 276 \\
\hline \multicolumn{9}{|l|}{ Outputs $\left(\mathrm{kg} \mathrm{ha}^{-1}\right)$} \\
\hline Manure degradation & 0 & 397 & 493 & 244 & 0 & 0 & 0 & 0 \\
\hline SOM degradation & 0 & 157 & 20 & 54 & 124 & 145 & 72 & 234 \\
\hline Erosion losses & 329 & 501 & 317 & 640 & 295 & 286 & 164 & 503 \\
\hline Total & 329 & 1,054 & 811 & 938 & 419 & 431 & 236 & 737 \\
\hline Balance $\left(\mathrm{kg} \mathrm{ha}^{-1}\right)$ & -156 & -148 & 118 & 87 & -129 & -206 & 106 & -461 \\
\hline
\end{tabular}

easily could have been lower because farmers left the applied fertilizers on the soil surface. This practice in combination with cultivation on steep slopes makes the fertilizers prone to losses due to run off, reducing both fertilizer recovery and efficiency.

The nutrient use inefficiencies are at least partly attributable to imbalances between macro-nutrients leading to constraints in yield due to limited availability in the maize crop of $\mathrm{N}$ and $\mathrm{K}$ while $\mathrm{P}$ was taken up in relative excess (Fig. 5). Visual observations of easily dislodged maize plants, poor cob formation and grain fill support the diagnosis of low K (Lopez and Vlek 2006). Poor nutrient interception by the roots may be another reason for the low $\mathrm{N}$ and K uptake (Fig. 4). Ball-Coelho et al. (1998) found more lateral and superficial distribution of maize roots under systems with no tillage such as the fields of our study area. This type of root development is beneficial for intercepting surface-applied fertilizers but unhelpful for intercepting nutrients that are leached deeper in the soil profile (Ball-Coelho et al. 1998). On the sandy soils in the area with low SOM contents both $\mathrm{N}$ and $\mathrm{K}$ are prone to leaching losses (Benton 2003; Ball-Coelho et al. 1998), contributing to further $\mathrm{N}$ and $\mathrm{K}$ deficits. These losses may also explain the difference between calculated potential $\mathrm{K}$ supply and measured $\mathrm{K}$ uptake, especially at high potential K supply rates (Fig. 4). Minjian et al. (2007) reported trends in China similar to the ones in our study, where unilateral emphasis on $\mathrm{N}$ and $\mathrm{P}$ fertilizers and declining OM inputs have led to wide- spread $\mathrm{K}$ deficiencies. The absence of $\mathrm{K}$ in subsidized fertilizer packages apparently prompted farmers to leave out $\mathrm{K}$ from their fertilizing strategies altogether. Currently, crop residues and soil stocks are the only sources of K. Field experiments with application of $\mathrm{K}$ fertilizer are needed to confirm the indications from this study.

Low soil $\mathrm{pH}$ was common in the sampled farmers' fields. It is well documented that soil acidity limits plant growth, nutrient uptake and yields due to low availability of nutrients (Granados et al. 1993; Baligar et al. 1997). Under acid soil conditions ammonification is largely carried out by fungi, and nitrification by bacteria is suppressed. The assimilated $\mathrm{N}$ flows into the pool of soil biota (Mengel 1996), thus reducing its availability to plants (Hodge et al. 2000). Liming is not a feasible option to raise soil $\mathrm{pH}$, due to lack of availability in the region, and costs of transportation and application to the fields. Application of organic matter and animal manure may offer an opportunity as they are known to increase soil $\mathrm{pH}$ over time (Ouédraogo et al. 2001; Eghball 2002; Eghball et al. 2004).

Another major cause of inefficiency was the large biomass of weeds which took up on average $40 \%$ of the total amount of N, 29\% of P and $44 \%$ of $\mathrm{K}$ (Table 3; Fig. 5). Weeds thrived despite high inputs of herbicides, at rates of four times and even higher than those recommended. These results showed that attention should be given to the efficacy of weed control as well as that of fertilizers. 
Also at the farm level (Table 5; Fig. 3), the results clearly indicate that purchased inputs had very low efficiencies. Based on actual inputs (Fig. 3) efficiencies were nil for $\mathrm{N}$ and 0.17 for $\mathrm{P}$. Efficiencies estimated with a whole-farm model (Table 5) were higher; 0.12 for $\mathrm{N}$ and 0.51 for $\mathrm{P}$, possibly due to underestimated erosion losses and lack of information on export of animal products. Farm nutrient use efficiency was not related to presence of animals that could contribute to better cycling of organic matter and nutrients on the farm by utilizing crop residues. This aspect requires further investigation, as data on where the animals were kept, how they were fed and how manure was collected and stored were based on interviews and expert opinion. However, manure input on farms with animals was an important source of organic matter, amounting to on average $50 \%$ of $\mathrm{OM}$ recycling on the farm and on average 13, 3 and $16 \mathrm{~kg} \mathrm{ha}^{-1}$ of $\mathrm{N}, \mathrm{P}$ and $\mathrm{K}$. Manure thus has potential as soil improving factor (Dogliotti et al. 2006; Herrero et al. 2010). However, this study confirmed other studies with smallholders in tropical areas that revealed that available manure did not match nutrient needs to sustain crop production (Tittonell et al. 2009; Rufino et al. 2010). We calculated that at the current production levels, the animals can only be fed for 105-130 days (data not shown). Giving attention to producing feed for the animals may provide additional sources of manure as well as income. This would require further elaboration in the region.

Estimated organic matter balances showed that the systems were close to equilibrium. Absolute levels of soil organic matter were generally close to those estimated using the relation proposed by Ruhlmann (1999) for minimum level of SOM (data not shown), suggesting that clearly positive OM balances would be desirable to enhance soil functioning. Higher crop yields are an effective way of increasing organic matter inputs through crop residues and roots. These additions may be further enhanced by growing leguminous intercrops which do not interfere with maize and roselle production in a negative way. Farmers stated that the soil is 'tired' and it is impossible to get yields without fertilizers. Fallowing to recover soil fertility was a common practice some 30 years ago but has been abandoned coinciding with artificial fertilizer availability and shortage of land. Currently, fallowing does not seem feasible in view of the small farm sizes, low production levels and household needs.

Soil erosion estimates classified the majority of fields as having moderate erosion $\left(10-50 \mathrm{Mg} \mathrm{ha}^{-1}\right.$ year $^{-1}$ ) which corresponds to the main class of erosion present in $37 \%$ of the land of the state of Guerrero (SEMARNAT and UACH 2002). Farmers voiced concerns over erosion, but saw this as part of the problem of low yields and loss of soil fertility. Land scarcity forced the farmers to practice agriculture on extremely steep slopes; the average slope in the sampled fields was $27 \%$. It has been demonstrated that residue retention provides protection from raindrop impact, and causes an increase in soil roughness reducing the runoff flow velocity and flow transport capacity. This also limits evaporation and is thereby increasing the amount of water available for plant uptake (Gilley et al. 1987; Fowler and Rockstrom 2001; Hartkamp 2002; Tiscareño et al. 2004). As a rule of thumb, $30 \%$ ground cover is recommended by various authors (Lal, 1976; Uri and Lewis 1999; Scopel et al. 2004; Tiscareño et al. 2004). More knowledge on the relation between ground cover and erosion is needed to understand the trade-off between crop residues for animal feed and for soil protection. Additionally, the feasibility of control measures such as terracing and strip cropping to prevent the runoff of water and erosion should be evaluated and integrated as part of the sustainable management and conservation of the resources (Sanders 2004; Kuypers et al. 2005).

Calculated erosion rates were higher than the tolerable soil loss limit proposed in the USA for $86 \%$ of the fields $\left(11.2 \mathrm{Mg} \mathrm{ha}^{-1}\right.$ year $^{-1}$ ) (El-Swaify et al. 1982). High erosion rates were particularly due to high slope-length (LS). Although threshold values may vary depending on type of soil and specific agroecological conditions (Skidmore 1982; Jha et al. 2009; $\mathrm{Li}$ et al. 2009), values in the area are cause for concern.

Contrary to expectation, differences in social organization between the two communities did not impact on any of the quantitative variables on nutrient use efficiency and crop yields. Also, differences between farms were not significant. In contrast, fields within farms and communities differed significantly, suggesting that field specific approaches are needed to understand and improve production conditions. 
Methodology

The methodology mobilized in this study relied as much as possible on observations and measurements that could be performed without sophisticated analytical equipment and that were supported by modelbased calculations. Important model-based calculations included soil erosion using RUSLE, soil production potentials using QUEFTS, and balances of soil organic matter and animal feed rations using Farm DESIGN. As much as possible information from similar Mexican production conditions was used, and conclusions from observations were used to crosscheck model-based results. QUEFTS requires validation of potential grain yield of local criollo varieties, recovery fractions and the integration of soil erosion. More detailed information on the animal component, e.g. feeding regimes, amount of time spending around the farm, manure collection systems, use of manure, would have increased the accuracy of calculations. Particularly for crop nutrient use efficiencies it was possible to obtain a consistent set of results using both measurements and models. Results on erosion and soil organic matter balances were based on modeling only, but resulted in estimates which for erosion were recognizable in the region, and for organic matter were plausible given the cropping history. Particularly for erosion, more detailed observations on the fate of crop residues in the course of the dry period, with and without animal exclusion would provide more information to support both erosion and organic matter balance calculations.

\section{Policy implications}

Price support of chemical fertilizers as a policy to maintain crop nutrition and improve yields has not been effective due to lack of balance in nutrient contents and the acidifying potential of the fertilizers (e.g. ammonium sulphate) (Akinrinde 2006) in the subsidized fertilizer packages. During the time of the study, only a single fertilizer subsidy package existed, which resulted in $75 \%$ price subsidy for $69 \mathrm{~kg} \mathrm{~N}$ and $30 \mathrm{~kg} \mathrm{P}$, meant for two ha. Farmer application rates showed that $\mathrm{P}$ application rates were well below those suggested in the subsidy package, while $\mathrm{N}$ application rates always exceeded the subsidized $69 \mathrm{~kg} \mathrm{ha}^{-1}$ for maize (Table 3). K content in biomass (Table 2) and potential soil K supply (Fig. 4) revealed K shortage on most of the fields. The lack of attention for $\mathrm{K}$ in the subsidies clearly was not compensated by purchase of $\mathrm{K}$. The subsidy scheme thus seems a clear case where the existing institutional environment has a major impact on resource use efficiencies. Without additional $\mathrm{K}$ input, low nutrient efficiencies will continue to exist for applied $\mathrm{N}$ and $\mathrm{P}$, along with low yields. The study suggests that a local integrated nutrient management policy is necessary to improve current crop nutrition, maintain or increase yields and enhance the soil fertility.

In agreement with farmers' demands (Table 1) alternative nutrient management strategies could be based on combining chemical and organic fertilizers. Composts as organic amendment will help to remedy the low soil $\mathrm{pH}$ in the longer term and are a feasible option in the municipality with the advent of a composting facility. Experiments are needed to evaluate the short-term effect of compost on biomass accumulation and yield. Finally, the strategy also needs to include increasing nutrient use efficiencies through improvements in weed control and cultivar choice. Well-structured experimentation by farmers and researchers may help to find locally adapted solutions.

Although implementation of OM input intensive systems faces the challenge of remote fields with only access on foot or horseback, such systems could be expected to show yield increases even in the short term (see e.g. Scholberg et al. 2010a, b) due to more balanced supply of nutrients and infiltration of water. Such change should be accompanied by other soil erosion measures as erosion constituted an important loss term in the OM balance. Production on the steepest slopes could be reconsidered, along with more attention for retaining soil cover. The latter needs to consider the communal land traditions, which cause cattle to strongly reduce soil cover by crop residues remaining at the start of the next rainy season (Herrero et al. 2010).

Aiming for an ecological intensification of cropping systems in Costa Chica is necessary to improve nutrient use efficiency. It implies promotion of integrated crop management that includes integration of organic and chemical sources of nutrients, multifunctional crops and crop residues management. These strategies can potentially enhance soil properties, conserve the resource base, reduce the reliance on external inputs, maintain crop yields, and minimize impact on the environment (Doran 2002). 
Acknowledgments We gratefully acknowledge the support of Dr Bert H. Janssen in applying the QUEFTS model, the help of ing. Jacques C.M. Withagen with the statistical analyses and the constructive comments of an anonymous referee.

Open Access This article is distributed under the terms of the Creative Commons Attribution Noncommercial License which permits any noncommercial use, distribution, and reproduction in any medium, provided the original author(s) and source are credited.

\section{References}

Akinrinde EA (2006) Issues of optimum nutrient supply for sustainable crop production in tropical developing countries. Pak J Nutr 5:387-397

Alcántar GG, Sandoval M (1999) Manual de Análisis Químico de Tejido Vegetal. Publicación Especial Número 10. Sociedad Mexicana de la Ciencia del Suelo. A. C. Chapingo México, p 156

Altieri M (2002) Agroecology: the science of natural resource management for poor farmers in marginal environments. Agric Ecosyst Environ 93:1-24

Baligar VC, Pitta GVE, Gama EEG, Schaffert RE, Bahia Filho AF, de C, Clark RB (1997) Soil acidity effects on nutrient use efficiency in exotic maize genotypes. Plant Soil 192:9-13

Ball-Coelho BR, Roy RC, Swanton CJ (1998) Tillage alters corn root distribution in coarse-textured soils. Soil Tillage Res 45:237-249

Benton JB (2003) Agronomic handbook. Management of crop, soils, and their fertility. CRC press, Boca Raton, p 484

Bremner JM (1965) Inorganic forms of nitrogen. In: Black CA, Evans DD, White JL, Ensminger LE, Clark FE (eds) Methods of soil analysis. Part 2. Agronomy 9. Madison, Am Soc Agron, pp 1179-1237

Burgess MS, Mehuys GR, Madramooto CA (2002) Nitrogen dynamics of decomposing corn residue components under three tillage systems. Soil Sci Soc Am J 66:1350-1358

Cassman KG (1999) Ecological intensification of cereal production systems: Yield potential, soil quality, and precision agriculture. Proc Natl Acad Sci USA 96:5952-5959

Chambers R (1994) Participatory rural appraisal (PRA): analysis of experience. World Dev 22:1253-1268

CIRAD (2010) La nature comme modèle, pour une intensification écologique de l'agriculture or Nature as a model for ecological intensification of agriculture. CIRAD, France

Clarke RT (1996) Residual maximum likelihood (REML) methods for analysing hydrological data series. J Hydrol 82:277-295

Colunga GB, Arriaga-Jordán CM, Veláquez Beltran CM, González-Ronquillo L, Smith M, Estrada-Flores DG, Rayas-Amor JA, Castelán-Ortega OA (2005) Participatory study on feeding strategies for working donkeys used by campesino farmers in the highlands of central México. Trop Anim Health Prod 37:143-157

Consejo Nacional de Población (2006) Índices de marginación 2005. CONAPO, México, pp 123-129
CVB (2008) Tabellenboek Veevoeding 2008 - Voedernormen landbouwhuisdieren en voederwaarden veevoeders. Centraal Voederbureau, Lelystad, CVB reeks nr 46, p 120

de Wit CT (1992) Resource use efficiency in agriculture. Agric Syst 40:125-151

Dixon J, Gulliver A, Gibbon D (2001) Farming systems and poverty. Improving farmers' livelihoods in a changing world. FAO-The World Bank, Rome and Washington

Dogliotti S, van Ittersum MK, Rossing WAH (2006) Influence of farm resource endowment on possibilities for sustainable development: a case study for vegetable farms in South Uruguay. J Environ Manage 78:305-315

Doran JW (2002) Soil health and global sustainability: translating science into practice. Agric Ecosyst Environ 88:119-127

Eghball B (2002) Soil properties as influenced by phosphorusand nitrogen-based manure and compost applications. Agron J 94:128-135

Eghball B, Ginting D, Gilley JE (2004) Residual effects of manure and compost applications on corn production and soil properties. Agron J 96:442-447

EI-Swaify SA, Dangler EW, Armstrong CL (1982) Soil Erosion by water in the tropics. Research Extension Series 024 . College of Tropical Agriculture and Human Resources, University of Hawaii, Hawaii

Figueroa SB, Cortes THG, Pimentel LJ, Osuna CES, Rodríguez OJM, Morales FFJ (1991) Manual de predicción de pérdida de suelo por erosión hídrica. Colegio de Postgraduados, Secretaria de Agricultura y Recursos Hidráulicos, México

Fowler R, Rockstrom J (2001) Conservation tillage for sustainable agriculture: an agrarian revolution gathers momentum in Africa. Soil Tillage Res 61:93-107

Gilley JE, Finkner SC, Varvel GE (1987) Slope length and surface residue influences on runoff and erosion. T ASABE 30:148-152

Grace PR, Jain MC, Harrington LW (2002) Environmental concerns in rice-wheat system. In: Proceedings of the international workshop on developing action program for farm level impact in rice-wheat system of the indo-gangetic plains, 25-27 September 2000 at New Delhi, India. RiceWheat consortium paper series 14, New Delhi, India: ricewheat consortium for the indo-gangetic plains

Granados G, Pandey S, Ceballos H (1993) Response to selection for tolerance to acid soils in a tropical population. Crop Sci 33:936-940

Groot JCJ, Oomen GJM (2011) FarmDESIGN manual. Wageningen University, Wageningen. URL: https://sites.google. $\mathrm{com} /$ site/farmdesignmodel/home

Harrington KC, Thatcher A, Kemp PD (2006) Mineral composition and nutritive value of some common pasture weeds. N Z Plant Prot 59:261-265

Hartkamp AD (2002) Learning from biophysical heterogeneity: inductive use of case studies for maize cropping systems in Central America. Dissertation, Wageningen University, Netherlands

Herrero M, Thornton PK, Notenbaert AM, Wood S, Msangi S, Freeman HA, Bossio D, Dixon J, Peters M, van de Steeg J, Lynam J, Parthasarathy Rao P, Macmillan S, Gerard B, McDermott J, Seré C, Rosegrant M (2010) Smart investments in sustainable food production: revisiting mixed crop-livestock systems. Science 327:822-825 
Hodge A, Robinson D, Fitter A (2000) Are microorganisms more effective than plants at competing for nitrogen? Trends Plant Sci 5:304-308

IAASTD (International Assessment of Agricultural Knowledge, Science and Technology for Development) (2009) Agriculture at a crossroads. Executive summary of the synthesis report. Island Press, USA

INEGI (ed) (2002) Tecoanapa, Estado de Guerrero. Cuaderno Estadistico Municipal, Mexico

Janssen BH, de Willigen P (2006) Ideal and saturated soil fertility as bench marks in nutrient management. 1. Outline of the framework. Agric Ecosyst Environ 116:132-146

Janssen BH, Guiking FCT, Van der Eijk D, Smaling EMA, Wolf J, Van Reuler H (1990) A system for quantitative evaluation of the fertility of tropical soils QUEFTS. Geoderma 46:299-318

Jha P, Nitant HC, Mandal D (2009) Establishing permissible erosion rates for various landforms in Delhi State, India. Land Degrad Dev 20:92-100

Kuypers H, Mollema A, Topper E (2005) Erosion control in the tropics. Agromisa Foundation, Digigrafi, Wageningen

Lal R (1976) Soil erosion on alfisols in Western Nigeria. I. Effects of slope, crop rotation and residue management. Geoderma 16:363-375

Li L, Du S, Wu L, Liu G (2009) An overview of soil loss tolerance. Catena 78:93-99

Liu BJ, Nearing MA, Shi PJ, Jia ZW (2000) Slope length effects on soil loss for steep slopes. Soil Sci Soc Am J 64:1759-1763

Lopez RC, Vlek PLG (2006) Potassium (K): principal constraint to maize production in Imperata-infested fields at Central Sulawesi, Indonesia. In: Proceedings conference on international agricultural research for development. Tropentang, Univesity of Bonn

Malézieux E, Crozat Y, Dupraz C, Laurans M, Makowski D, Ozier-Lafontaine H, Rapidel B, de Tourdonnet S, ValantinMorison M (2009) Mixing plant species in cropping systems: concepts, tools and models. A review. Agron Sust Dev 29:43-62

Mengel K (1996) Turnover of organic nitrogen in soils and its availability to crops. Plant Soil 181:83-93

Minjian C, Haiqiu Y, Hongkui Y, Chunji J (2007) Difference in tolerance to potassium deficiency between two maize inbred lines. Plant Prod Sci 10:42-46

Mitra SP, Shanker H (1957) Amelioration of alkali soil by chemicals in combination with organic-matter-like weeds. Soil Sci 83:471-474

Mourits MCM, Berentsen PBM, Huirne RBM, Dijkhuizen AA (2000) Environmental impact of heifer management decisions on Dutch dairy farms. Neth J Agric Sci 48:151-164

Nearing MA (1997) A single, continuous function for slope steepness influence on soil loss. Soil Sci Soc Am J 61:917-919

Nijhof K (1987) Concentration of macro-elements in economic products and residues of (sub) tropical field crops. Centre for World Food Studies, staff working paper SWO-87-08. Wageningen, The Netherlands

Ouédraogo E, Mando A, Zombré NP (2001) Use of compost to improve soil properties and crop productivity under low input agricultural system in West Africa. Agriculture Agric Ecosyst Environ 84:259-266
Presidencia Municipal de Tecoanapa, Gro., Instituto de Investigación Científica Área Ciencias Naturales-UAG (2001) Fertilidad de Suelos agrícolas e hidrológica del municipio de Tecoanapa, Guerrero, México

Pretty J (1995) Participatory learning for sustainable agriculture. World Dev 23:1247-1263

Pretty J (1997) The sustainable intensification of agriculture. Nat Resour Forum 21:247-256

Renard KG, Foster GR, Weesies GA, Mc Cool DK, Yoder DC (1997) Predicting soil erosion by water: a guide to conservation planning with the Revised Universal Soil Loss Equation (RUSLE). Agriculture handbook no. 703 United States Department of Agriculture

Rodríguez J (1993) La fertilidad de los cultivos, un método racional. Facultad de Agronomía P.U.C, Chile

Röling NG, Hounkonnou D, Offei SK, Tossou R, van Huis A (2004) Linking science and farmers' innovative capacity: diagnostic studies from Ghana and Benin NJAS Wagen. J Life Sci 52:211-235

Rufino MC, Dury J, Tittonell P, van Wijk MT, Herrero M, Zingore S, Mapfumo P, Giller KE (2010) Collective management of feed resources at village scale and the productivity of different farm types in a smallholder community of North East Zimbabwe. Agric Syst. doi: 10.1016/j.agsy.2010.06.001

Rühlmann J (1999) A new approach to estimating the pool of stable organic matter in soil using data from long-term field experiments. Plant Soil 213:149-160

Safley M (1998) How traditional agriculture is approaching sustainability. Biomass Bioenerg 4:329-332

Sanders D (2004) Soil conservation, in land use,land cover and soil sciences. In: Verheye WH (ed) Encyclopedia of Life Support Systems (EOLSS), Developed under the Auspices of the UNESCO, Eolss Publishers, Oxford, UK, http://www.eolss.net. Accessed Apr 2011

Scholberg JMS, Doglotti S, Leoni C, Cherr CM, Zotarelli L, Rossing WAH (2010a) Cover crops for sustainable agrosystems in the Americas. In: Lichtfouse E (ed) Genetic engineering, biofertisation, soil quality and organic farming, sustainable agricultural reviews, vol 4. Springer, Dordrecht, pp 23-58

Scholberg JMS, Doglotti D, Zotarelli L, Cherr CM, Leoni C, Rossing WAH (2010b) Cover crops in agroecosystems: innovations and applications. In: Lichtfouse L (ed) Genetic engineering, biofertisation, soil quality and organic farming, sustainable agricultural reviews, vol 4. Springer, Dordrecht, pp 59-99

Scopel E, da Silva FAM, Corbeels M, Affholder F, Maraux F (2004) Modelling crop residue mulching effects on water use and production of maize under semi-arid and humid tropical conditions. Agronomie 24:383-395

SEMARNAT-UACH (2002) Evaluación de la pérdida de suelo por erosión hídrica y eólica en la Republica Mexicana, escala 1: 1000,000. México

Setiyono TD, Walters DT, Cassman KG, Witt C, Dobermann A (2010) Estimating maize nutrient uptake requirements. Field Crop Res 118:158-168

Skidmore EL (1982) Soil loss tolerance. In: Determinants of soil loss tolerance. American Society of Agronomy special publication no. 45. Madison, WI. American Society of Agronomy, Soil Science Society of America, pp 87-93 
Tiscareño ML, Velásquez MV, Salinas JG, Báez ADG (2004) Nitrogen and organic matter losses in no-till corn cropping systems. J Am Water Resour Assoc 40:401-408

Tittonell P, Vanlauwe B, Corbeels M, Giller KE (2008) Yield gaps, nutrient use efficiencies and response to fertilisers by maize across heterogeneous smallholder farms of western Kenya. Plant Soil 313:19-37

Tittonell P, van Wijk MT, Herrero M, Rufino MC, de Ridder N, Giller KE (2009) Beyond resource constraints-exploring the biophysical feasibility of options for the intensification of smallholder crop-livestock systems in Vihiga district, Kenya. Agric Syst 101:1-19

Uri ND, Lewis JA (1999) Agriculture and the dynamics of soil erosion in the United States. Journal Sust Agric 14:63-81 van Keulen H (1982) Graphical analysis of annual crop response to fertiliser application. Agric Syst 9:113126

van Reuler H, Janssen BH (1996) Optimum NPK management over extended cropping periods in south-west Côte d'Ivoire. Neth J Agric Sci 44:263-277

West TO, Post WM (2002) Soil organic carbon sequestration rates by tillage and crop rotation: a global data analysis. Soil Sci Soc Am J 66:1930-1946

Yang HS, Janssen BH (2000) A mono-component model of carbon mineralization with a dynamic rate constant. Eur J Soil Sci 51:517-529

Ye XJ, Wang ZQ, Lu JB (2002) Participatory assessment and planning approach: conceptual and process issues. J Sust Agric 20:89-111 